\title{
DNA sequence polymorphisms in a panel of eight candidate bovine imprinted genes and their association with performance traits in Irish Holstein-Friesian cattle
}

David A Magee ${ }^{1 *}$, Klaudia M Sikora ${ }^{2,3}$, Erik W Berkowicz ${ }^{1}$, Donagh P Berry ${ }^{4}$, Dawn J Howard ${ }^{5}$, Michael P Mullen ${ }^{4}$, Ross D Evans ${ }^{6}$, Charles Spillane ${ }^{2}$, David E MacHugh ${ }^{1,7}$

\begin{abstract}
Background: Studies in mice and humans have shown that imprinted genes, whereby expression from one of the two parentally inherited alleles is attenuated or completely silenced, have a major effect on mammalian growth, metabolism and physiology. More recently, investigations in livestock species indicate that genes subject to this type of epigenetic regulation contribute to, or are associated with, several performance traits, most notably muscle mass and fat deposition. In the present study, a candidate gene approach was adopted to assess 17 validated single nucleotide polymorphisms (SNPs) and their association with a range of performance traits in 848 progenytested Irish Holstein-Friesian artificial insemination sires. These SNPs are located proximal to, or within, the bovine orthologs of eight genes (CALCR, GRB10, PEG3, PHLDA2, RASGRF1, TSPAN32, ZIM2 and ZNF215) that have been shown to be imprinted in cattle or in at least one other mammalian species (i.e. human/mouse/pig/sheep).
\end{abstract}

Results: Heterozygosities for all SNPs analysed ranged from 0.09 to 0.46 and significant deviations from HardyWeinberg proportions $(P \leq 0.01)$ were observed at four loci. Phenotypic associations $(P \leq 0.05)$ were observed between nine SNPs proximal to, or within, six of the eight analysed genes and a number of performance traits evaluated, including milk protein percentage, somatic cell count, culled cow and progeny carcass weight, angularity, body conditioning score, progeny carcass conformation, body depth, rump angle, rump width, animal stature, calving difficulty, gestation length and calf perinatal mortality. Notably, SNPs within the imprinted paternally expressed gene 3 (PEG3) gene cluster were associated $(P \leq 0.05)$ with calving, calf performance and fertility traits, while a single SNP in the zinc finger protein 215 gene (ZNF215) was associated with milk protein percentage $(P \leq 0.05)$, progeny carcass weight $(P \leq 0.05)$, culled cow carcass weight $(P \leq 0.01)$, angularity $(P \leq 0.01)$, body depth $(P \leq 0.01)$, rump width $(P \leq 0.01)$ and animal stature $(P \leq 0.01)$.

Conclusions: Of the eight candidate bovine imprinted genes assessed, DNA sequence polymorphisms in six of these genes (CALCR, GRB10, PEG3, RASGRF1, ZIM2 and ZNF215) displayed associations with several of the phenotypes included for analyses. The genotype-phenotype associations detected here are further supported by the biological function of these six genes, each of which plays important roles in mammalian growth, development and physiology. The associations between SNPs within the imprinted PEG3 gene cluster and traits related to calving, calf performance and gestation length suggest that this domain on chromosome 18 may play a role regulating pre-natal growth and development and fertility. SNPs within the bovine ZNF215 gene were associated with bovine growth and body conformation traits and studies in humans have revealed that the human ZNF215 ortholog belongs to the imprinted gene cluster associated with Beckwith-Wiedemann syndrome-a genetic

\footnotetext{
* Correspondence: david.magee@ucd.ie

'Animal Genomics Laboratory, UCD School of Agriculture, Food Science and

Veterinary Medicine, University College Dublin, Belfield, Dublin 4, Ireland

Full list of author information is available at the end of the article
}

(C) 2010 Magee et al; licensee BioMed Central Ltd. This is an Open Access article distributed under the terms of the Creative Commons 
disorder characterised by growth abnormalities. Similarly, the data presented here suggest that the ZNF215 gene may have an important role in regulating bovine growth. Collectively, our results support previous work showing that (candidate) imprinted genes/loci contribute to heritable variation in bovine performance traits and suggest that DNA sequence polymorphisms within these genes/loci represents an important reservoir of genomic markers for future genetic improvement of dairy and beef cattle populations.

\section{Background}

Single nucleotide polymorphisms (SNPs) are the most abundant and widespread form of DNA sequence variation in vertebrate genomes [1]. By illustration, information on over 2.3 million pan-genomic SNPs has been generated via the analysis of the $7.1 \times$ bovine genome sequence assembly and this number is expected to increase with data from continuing re-sequencing projects $[2,3]$. Furthermore, as the vast majority of SNPs are biallelic they can be analysed using low-to-high throughput genotyping platforms, such as the BovineSNP50 assay [4], whereby SNPs are queried digitally for the presence or absence of a specific allele. These features have resulted in the rapid emergence of SNPs as the genetic marker of choice for the analysis of DNA sequence variation in single or small numbers of genes and whole livestock genomes [5].

High-density SNP data generated for livestock species using commercially available genotyping arrays have greatly enhanced the detection, mapping and characterisation of quantitative trait loci (QTL) for complex performance traits. However, in some cases the gene(s) or causative mutations underlying a particular QTL remain elusive because many SNPs included on genotyping platforms are located in non-coding regions of the genome. Therefore, animal geneticists often employ candidate gene strategies as viable alternatives to genomewide scans for the detection of genes and DNA sequence/structural variation underling quantitative traits. The candidate gene approach uses variation in genes of known biological function relevant to the trait (s) of interest to investigate genotype-phenotype associations [6,7].

Previously, we adopted a candidate gene approach to detect genotype associations with performance in beef cattle by analysing SNPs in the bovine orthologs of genes shown to be imprinted in cattle or other mammalian species [8]. Genetic (or 'genomic') imprinting refers to the partial or complete transcriptional silence of one of the two parentally-inherited alleles that occurs in mammals in a parent-of-origin manner [9-11]. Genetic imprinting represents a recognisable form of epigenetic regulation in which chemical marks or "imprints", generally in the form of methyl groups $\left(-\mathrm{CH}_{3}\right)$, are added to specific nucleotides across a gene sequence (e.g. CpG dinucleotides within the promoter sequence) during gametogenesis to regulate expression. These imprints are stably transmitted to the embryo and are further maintained in somatic cells with the pattern of imprinting for many of these genes being both developmental stage- and tissue-specific [12,13].

Studies in humans and mice have identified over 100 genes that are subject to imprinting and there is a substantial body of scientific evidence that highlights the importance of these genes in regulating mammalian development, metabolism and physiology [12-16]. More recently, there is accumulating evidence from studies in mammalian livestock species that polymorphisms within imprinted loci contribute to, or are associated with, heritable variation in several complex performance traits-most notably muscle mass, fat deposition, growth and milk production [17-27]. Additionally, there has been increased interest in the evolutionary consequences of imprinted loci in animal breeding systems and how parent-of-origin effects can be incorporated into statistical models for quantitative genetic analyses [28-31].

In the current study, we report our findings from analyses of genotype-phenotype associations between 17 validated SNPs distributed across eight candidate bovine imprinted genes/loci and genetic merit for a range of performance traits in progeny-tested Irish Holstein-Friesian dairy sires. These genes/loci are the calcitonin receptor gene $(C A L C R)$, the growth factor receptorbound protein 10 gene (GRB10) [or maternally expressed gene 1 (MEG1)], paternally expressed gene 3 (PEG3), the pleckstrin homology-like domain, family A gene (PHLDA2), the RAS protein-specific guanine nucleotide-releasing factor 1 gene (RASGRF1), the tetraspanin 32 gene (TSPAN32), the zinc finger imprinted 2 gene (ZIM2), and the zinc finger protein 215 gene (ZNF215).

One of these genes (PEG3) has been previously shown to be imprinted in cattle $[32,33]$, while the imprinting status of one bovine ortholog (GRB10) is equivocal [34]. No data regarding the imprinting status in cattle currently exist for five of these genes (CALCR, PHLDA2, RASGRF1, TSPAN32 and ZNF215); however, all five genes have been shown to be imprinted in one or more mammalian species (i.e. human/mouse/pig/sheep) [14-16]. Although species-specific imprinting has been documented previously for some genes $[9,35]$, the appreciable conservation of genetic imprinting patterns 
between human and mouse [36,37] and humans and pigs [38] suggests that a proportion of the genes selected for analysis in the current study may also be imprinted in cattle. Furthermore, the documented molecular function of the encoded products of these genes suggests that they all play a pivotal role in mammalian growth and development and hence may represent potential and hitherto untested candidates for underlying variation in agro-economic traits.

The final gene analysed-zinc finger, imprinted 2 (ZIM2)-has recently been shown to be biallelically expressed in bovine testis tissue [32]. However, maternal imprinting of ZIM2 (i.e. expression from the padumnal allele) in humans and polymorphic imprinting of ZIM2 in mice (i.e. preferential maternal expression in brain tissue and biallelic expression in mouse testis), suggest a complex pattern of imprinting for this gene in different mammalian lineages [32]. ZIM2 forms an imprinted cluster or domain with the PEG3 gene in mammals $[32,39]$ and this gene cluster has been implicated previously in playing a role in mammalian growth and development [40-42]. Consequently, SNPs within the bovine ortholog of the ZIM2 gene were included for the analyses presented here.

\section{Methods}

\section{Single nucleotide polymorphisms (SNPs) selected for genotyping in the current study}

A panel of 17 SNPs distributed across the bovine orthologs of eight genes (CALCR, GRB10, PEG3, PHLDA2, RASGRF1, TSPAN32, ZIM2 and ZNF215)-each of which have been shown to be imprinted in either cattle, human, mouse, pigs or sheep or more than one of these species-were selected for medium-throughput genotyping in this study. The ENSEMBL database (http://www. ensembl.org) accession for each of these genes together with their reported imprinted status in cattle or other mammalian species and the role of their encoded protein products are detailed in Table 1.

Details for the 17 SNPs analysed in this study are presented in Table 2. Thirteen of these SNPs were previously validated via re-sequencing of high-fidelity polymerase chain reaction (PCR) products [8]. Information for three SNPs-distributed between the bovine CALCR gene (two SNPs) and PHLDA2 gene (one SNP)-was taken directly from the ENSEMBL database (these three SNPs were not validated by us via DNA re-sequencing previously or in the current study). The final SNP (RASGRF1_p. $C 25039690 T$ ) represents a de novo polymorphism located between the $7^{\text {th }}$ and $8^{\text {th }}$ exon of the bovine RASGRF1 gene on Bos taurus chromosome 21 (BTA21) and is presented for the first time here. This SNP was detected by sequencing a 1,095 base pair (bp) bovine RASGRF1-specific PCR product generated in a panel of 17 unrelated European
B. taurus samples using amplification conditions detailed elsewhere [8] and two previously unpublished PCR primer sequences [forward primer: 5'-GCT TTC CTG AAT CTC TAT GC-3'; reverse primer 5'-TAG GAT TGA TGA GGT GAT CC-3'].

Where possible, SNPs were labelled in the present study based on their dbSNP database accession number [43]; [http://www.ncbi.nlm.nih.gov/projects/SNP]; however, four of the SNPs analysed here (GRB10_p.A5394141C, PEG3_p.A64370595G, PEG3_p.C64367437T, RASGRF1_p. $C 25039690 T$ ) were not deposited in the dbSNP database at the time of analysis. Instead, these four SNPs were recoded according to the nomenclature adopted by Magee et al. [8]. For example, the de novo RASGRF1_p. $C 25039690 T$ SNP was labelled whereby the gene associated with the SNP (i.e. RASGRF1) is reported first, followed by: (1) the symbol '_p.' which denotes a genomic DNA polymorphism; (2) the first allele at the SNP (i.e. a ' $C$ ' allele); (3) the nucleotide position of the SNP (i.e. $25,039,690$ ) on BTA21 as per Build 4.0, release 59 , of the $B$. taurus reference genome, and (4) the second allele at this locus (i.e. a 'T' allele). The GRB10_p.A5394141C, PEG3_p.A64370595G and PEG3_p.C64367437T SNPs were labelled in the same manner for this study.

Based on the current open reading frame (ORF) gene model reported for each gene in the ENSEMBL database, two SNPs were located upstream of the nearest gene, five SNPs were synonymous coding exonic substitutions, one SNP was a non-synonymous coding exonic substitution (resulting in an asparagine-to-aspartic amino acid substitution at amino acid position 116 of the CALCR gene), five SNPs were intronic and four SNPs were located in 3'UTRs (Table 2). All SNPs were biallelic and of these 13 were transitions (76.5\%), while the remaining four were transversions (23.5\%).

\section{Single nucleotide polymorphism (SNP) genotyping and the DNA samples analysed}

All genotyping was performed by Sequenom Inc. (San Diego, CA, USA) using their proprietary MassARRAY iPLEX(tm) Gold platform (http://www.sequenom.com) and genomic DNA (gDNA) from 914 Irish Holstein-Friesian artificial insemination (AI) sires. gDNA from all 914 sires was extracted using a Maxwell(tm) 16 automated nucleic acid extraction apparatus (Promega Corp., Madison, WI, USA) according to manufacturer's instructions. The MassARRAY iPLEX(tm) Gold SNP genotyping platform discriminates between SNP alleles using single base primer extension technology after which primer extension products are analysed using matrix-assisted laser desorption ionization time-of-flight (MALDI-TOF) mass spectroscopy (http://www.sequenom.com/iplex). The 914 Holstein-Friesian sires have been used to generate progeny in Ireland and were representative of the commercial 
Table 1 The eight candidate bovine imprinted genes analysed in this study

\begin{tabular}{|c|c|c|c|c|c|}
\hline Gene & Ensembl gene ID & BTA $^{1}$ & Gene function $^{2}$ & $\begin{array}{l}\text { Imprinting } \\
\text { status in } \\
\text { cattle }\end{array}$ & $\begin{array}{l}\text { Additional species in which gene is } \\
\text { imprinted/Preferentially-expressed allele }\end{array}$ \\
\hline CALCR & ENSBTAG00000017458 & 4 & $\begin{array}{l}\text { Involved in regulating calcium } \\
\text { homeostasis; involved in } \\
\text { osteoclast-mediated bone resorption }\end{array}$ & $\begin{array}{l}\text { No data } \\
\text { available }\end{array}$ & $\begin{array}{l}\text { Human; Mouse/Maternal expression in both } \\
\text { species }\end{array}$ \\
\hline GRB10 & ENSBTAG00000017086 & 4 & $\begin{array}{l}\text { Involved in signal transduction; interacts } \\
\text { with insulin receptors and insulin-like } \\
\text { growth factor receptors }\end{array}$ & $\begin{array}{l}\text { Tested but } \\
\text { unconfirmed }^{4}\end{array}$ & $\begin{array}{l}\text { Human; Mouse; Sheep/Isoform-dependent } \\
\text { maternal and paternal expression }\end{array}$ \\
\hline ZNF215 & ENSBTAG00000003638 & 15 & $\begin{array}{l}\text { Putative role in transcriptional } \\
\text { regulation }\end{array}$ & $\begin{array}{l}\text { No data } \\
\text { available }\end{array}$ & $\begin{array}{l}\text { Human/Maternal expression but } \\
\text { biallelic expression has been reported in some } \\
\text { tissues }\end{array}$ \\
\hline PEG3 & ENSBTAG00000023338 & 18 & Role in cellular apoptosis & $\begin{array}{l}\text { Imprinted, } \\
\text { paternal } \\
\text { expression }^{5}\end{array}$ & $\begin{array}{l}\text { Human; Mouse; Sheep/Paternal expression in all } \\
\text { species }\end{array}$ \\
\hline ZIM2 & ENSBTAG00000011664 & 18 & Putative role in transcriptional regulation & $\begin{array}{l}\text { Biallelic } \\
\text { expression }^{6}\end{array}$ & $\begin{array}{l}\text { Human; Mouse/Paternal expression in humans. } \\
\text { Tissue-specific maternal and biallelic expression } \\
\text { has been reported in mouse }\end{array}$ \\
\hline RASGRF1 & ENSBTAG00000019940 & 21 & $\begin{array}{l}\text { Signal transduction and } \\
\text { cellular proliferation }\end{array}$ & $\begin{array}{l}\text { No data } \\
\text { available }\end{array}$ & Mouse/Paternal expression \\
\hline PHLDA2 & ENSBTAG00000031194 & 29 & Tumour suppressor gene & $\begin{array}{l}\text { No data } \\
\text { available }\end{array}$ & Human; Mouse; Pig/Maternal expression \\
\hline TSPAN32 & ENSBTAG00000002702 & 29 & $\begin{array}{l}\text { Possible tumour-suppressor } \\
\text { functions }\end{array}$ & $\begin{array}{l}\text { No data } \\
\text { available }\end{array}$ & $\begin{array}{l}\text { Mouse/Developmental-stage specific maternal } \\
\text { expression }\end{array}$ \\
\hline
\end{tabular}

Information regarding the expressed allele for all eight genes is based on the patterns of imprinting in mouse and human and, where possible, cattle, sheep and pigs. The chromosomal location of each gene was obtained from the ENSEMBL database (http://www.ensembl.org) and are based on Build 4.0, Ensembl release

59, of the B. taurus genome sequence (August 2010). The ENSEMBL database gene identity (ID) for each gene is given.

${ }^{1}$ B. taurus chromosome number.

${ }^{2}$ Data taken from the GeneCards Version 3 database [64]; [http://www.genecards.org].

${ }^{3}$ Data taken from the Catalogue of Parent-of-Origin Effects database [16] and the Geneimprint database [14].

${ }^{4}$ Tveden-Nyborg et al. [34].

${ }^{5}$ Khatib et al. [35].

${ }^{6}$ Kim et al. [32]; Kim et al. [33].

germplasm used in Irish dairy herds in recent years. For genotype quality control purposes, a panel of 25 independently-extracted, duplicate samples were also included for genotyping with the gDNA from 914 sires.

Genotype quality control and data filtering were performed on all data prior to association analyses. This involved the use of an iterative algorithm to remove SNPs and individuals that yielded poor genotype call rates. Firstly, SNPs with a genotype call rate $75 \%$ across all 914 individuals were removed, followed by the removal of individuals with genotype call rates of $85 \%$ across all remaining SNPs-this resulted in the removal of 21 sires and no SNPs from the study. Secondly, SNPs that yielded genotypes in $90 \%$ of all remaining 893 individuals were discarded followed by the removal individuals that failed to yield a genotype for $90 \%$ of all remaining SNPs-this resulted in the removal of a further 45 sires from the study, while no SNPs were discarded after the second filtering process.

After data filtering, genotypic data for all 17 SNPs and 848 progeny-tested sires with an average co-ancestry of $2.2 \%$ remained. A SNP genotype concordance rate of 99\% between technical replicate samples was observed across all 17 SNPs; where discordance existed between the technical replicates the genotype for the sample in question was set to missing. Summary statistics for each SNP (including allele and genotype frequencies) and phenotype association analyses were performed using this edited dataset. $D^{\prime}$ [44] and $r^{2}$ [45] estimates of linkage disequilibrium (LD) between every pairwise combination of segregating SNPs within each gene/locus and imprinted gene cluster (i.e. the PEG3 imprinted gene cluster on B. taurus chromosome 15 [BTA15] that contains SNPs associated with the PEG3 and ZIM2 genes) were also generated from this edited dataset using the HAPLOVIEW software package [46].

\section{Phenotypic data and SNP genotype-phenotype association analyses}

A range of phenotypic traits were analysed in this study and these were subdivided into seven broad categories: (1) milk production traits [milk yield, milk fat yield, milk protein yield, milk fat percentage and protein percentage]; (2) udder/animal health [somatic cell count]; (3) carcass traits [cow carcass weight, progeny carcass weight, progeny carcass (subcutaneous) fat level and 
Table 2 Information for the SNPs genotyped in this study and summary statistics for the 848 genotyped Irish Holstein-Friesian Al sires

\begin{tabular}{|c|c|c|c|c|c|c|c|c|}
\hline Gene/Expressed allele & BTA & SNP ID ${ }^{1}$ & $\begin{array}{l}\text { Nucleotide } \\
\text { position of SNP }\end{array}$ & $\begin{array}{l}\text { SNP gene } \\
\text { position }\end{array}$ & $\begin{array}{l}\text { Alleles } \\
(1 / 2)^{2}\end{array}$ & $\begin{array}{l}\text { Frequency } \\
\text { allele } 1(p)^{3}\end{array}$ & Heterozygosity & $\begin{array}{c}\text { Deviation } \\
\text { from HWE }\end{array}$ \\
\hline \multirow[t]{2}{*}{ CALCR/maternal } & 4 & rs42940189 & $11,049,538$ & $\begin{array}{l}\text { Exonic } \\
\text { (non-syn) }\end{array}$ & $\mathrm{G} / \mathrm{A}$ & 0.90 & 0.15 & $<0.001$ \\
\hline & 4 & rs42940187 & $11,039,296$ & $\begin{array}{l}\text { Exonic } \\
\text { (syn) }\end{array}$ & $\mathrm{C} / \mathrm{T}$ & 0.86 & 0.23 & 0.03 \\
\hline \multirow[t]{2}{*}{$\begin{array}{l}\text { GRB10/ } \\
\text { isoform-dependent }\end{array}$} & 4 & $\begin{array}{l}\text { GRB10_p. } \\
\text { A5394141C }\end{array}$ & $5,394,141$ & Intronic & $\mathrm{C} / \mathrm{A}$ & 0.95 & 0.09 & 0.11 \\
\hline & 4 & rs43375833 & $5,334,910$ & Intronic & $\mathrm{C} / \mathrm{T}$ & 0.67 & 0.42 & 0.14 \\
\hline \multirow[t]{2}{*}{ ZNF215/maternal } & 15 & rs42575466 & $44,945,003$ & $\begin{array}{l}\text { Exonic } \\
\text { (syn) }\end{array}$ & $\mathrm{G} / \mathrm{A}$ & 0.95 & 0.09 & $<0.00001$ \\
\hline & 15 & rs42575474 & $44,934,196$ & Intronic & $\mathrm{G} / \mathrm{A}$ & 0.67 & 0.43 & 0.46 \\
\hline \multirow[t]{3}{*}{ PEG3/paternal } & 18 & $\begin{array}{l}\text { PEG3_p. } \\
\text { A64370595G }\end{array}$ & $64,370,595$ & Upstream & $\mathrm{G} / \mathrm{A}$ & 0.69 & 0.44 & 0.36 \\
\hline & 18 & $\begin{array}{l}\text { PEG3_p. } \\
\text { C64367437T }\end{array}$ & $64,367,437$ & Upstream & $\mathrm{C} / \mathrm{T}$ & 0.66 & 0.45 & 0.81 \\
\hline & 18 & rs 17871322 & $64,362,259$ & $\begin{array}{l}\text { Exonic } \\
\text { (syn) }\end{array}$ & $\mathrm{G} / \mathrm{A}$ & 0.66 & 0.46 & 0.43 \\
\hline \multirow{4}{*}{$\begin{array}{l}\text { ZIM2/ } \\
\text { paternal expression in humans; } \\
\text { polymorphic expression in mice }\end{array}$} & 18 & rs41899915 & $64,234,488$ & $\begin{array}{l}\text { Exonic } \\
\text { (syn) }\end{array}$ & $C / G$ & 0.80 & 0.32 & 0.43 \\
\hline & 18 & rs41899913 & $64,233,519$ & 3'UTR & $\mathrm{G} / \mathrm{C}$ & 0.83 & 0.28 & 0.85 \\
\hline & 18 & rs41899911 & $64,232,216$ & 3'UTR & $\mathrm{C} / \mathrm{T}$ & 0.80 & 0.32 & 0.41 \\
\hline & 18 & rs41899910 & $64,231,503$ & 3'UTR & $\mathrm{T} / \mathrm{C}$ & 0.70 & 0.40 & 0.28 \\
\hline RASGRF1/paternal & 21 & $\begin{array}{l}\text { RASGRF1_p. } \\
\text { C25039690T }\end{array}$ & $25,039,690$ & Intronic & $A / G$ & 0.59 & 0.42 & $<0.001$ \\
\hline PHLDA2/maternal & 29 & rs42194502 & $50,555,723$ & 3'UTR & $\mathrm{A} / \mathrm{T}$ & 0.90 & 0.18 & 0.17 \\
\hline \multirow[t]{2}{*}{ TSPAN32/maternal } & 29 & rs42637579 & $51,123,847$ & Intronic & $\mathrm{G} / \mathrm{A}$ & 0.63 & 0.42 & $<0.01$ \\
\hline & 29 & rs42637578 & $51,123,729$ & $\begin{array}{l}\text { Exonic } \\
\text { (syn) }\end{array}$ & $\mathrm{T} / \mathrm{C}$ & 0.94 & 0.11 & 0.32 \\
\hline
\end{tabular}

Genotype and allele frequencies and the significance of deviations from Hardy-Weinberg equilibrium (HWE) based on $P$-values obtained from $\chi^{2}$-test results are shown for all 17 SNPs. All SNP nucleotide positions were obtained from the Build 4.0 of the $B$. taurus genome sequence on the ENSEMBL database (http://www. ensembl.org) or the UCSC genome browser (http://genome.ucsc.edu). The ORF gene model positions for each SNP are given. For exonic SNPs, amino acid sequence changing SNPs (i.e. non-synonymous SNPs, denoted 'non-syn') and non-amino acid sequence changing SNPs (i.e. synonymous SNPs, denoted 'syn') are shown. The imprinting status of each gene is based on data from human and mice and, where possible, cattle, sheep and pigs [14,16].

${ }^{1}$ Where possible, SNP identities (IDs) are given as per their entry in the dbSNP database [43]; [http://www.ncbi.nIm.nih.gov/projects/SNP]. Where no dbSNP ID was available, SNPs were labelled as per nomenclature used by Magee et al. [8] as detailed in the main body text of the manuscript.

${ }^{2}$ Alleles 1 and 2 represent the major and minor alleles, respectively, at a given SNP.

${ }^{3}$ The frequency of allele $1(p)$, the major allele at a SNP locus.

progeny carcass conformation]; (4) growth related traits in live animals [animal stature, chest width, body depth, rump angle, rump width]; (5) subjectively assessed subcutaneous fat level on live animals [angularity and body condition score]; (6) calving traits [direct calving difficulty, maternal calving difficulty, perinatal mortality and calf survival]; and (7) fertility [gestation length and calving interval]. A detailed description of the phenotypic traits analysed in this study are provided in Additional File 1.

The phenotypes used in this study are sire genetic merit based not on data on the sires themselves but on the performance of their female progeny across multiple generations. Using known relationships among animals, performance records on relatives are used to estimate the genetic merit of an animal (i.e. a sire). Systematic environmental effects on the progeny are adjusted for and the random non-genetic variation associated with the progeny's phenotypes is minimised, thus facilitating a more accurate measure of genetic merit. This increased study power is particularly beneficial for low heritability traits where the proportion of phenotypic variance attributable to additive genetic differences is low. The disadvantage of such a study design is that the performance traits included for analysis are limited to those routinely measured on progeny. The average number of progeny per sire analysed here was 842 daughter-parity records. When coupled with the mixed model methodology used and the de-regression of the predicted transmitting ability (PTA), this implies that the associations reported herein are independent of pedigree structure. 
Sire PTA was the dependent variable for all traits with the exception of the milk production traits, including somatic cell count, which were daughter yield deviations (DYDs) expressed on a PTA scale. Models used in genetic evaluations in Ireland, as well as variance components, have been previously described in detail [47] and summarised by Waters and colleagues [48]. All PTAs were de-regressed using the procedure outlined by Berry and colleagues [49]. Only sires with a reliability score, less parental contribution, of $>60 \%$ were retained for inclusion in the association analysis. A total of 742 sires fulfilled these criteria for inclusion in the analysis of milk, fat and protein yield as well as milk fat and protein concentration; the number of sires included in the association analysis with calving interval and survival was 501, and 477, respectively. The number of sires for direct calving difficulty, maternal calving difficulty, and perinatal mortality was 575,506 , and 201, respectively. The number of sires with a reliability of $>60 \%$ for the carcass traits was 446 and the number of sires with a reliability of $>60 \%$ for the size linear type traits varied from 484 to 551 .

The association between each SNP and performance was quantified using weighted mixed linear models in ASREML [50] with individual included as a random effect, and average expected relationships among individuals accounted for through the numerator relationship matrix. Year of birth (divided into five-yearly intervals) and percent Holstein of the individual sire were included as fixed effects in the model. In all instances the dependent variable was de-regressed PTA or DYD, weighted by their respective reliability, less the parental contribution. Genotype was included in the analysis as a continuous variable coded as the number of copies of a given allele.

\section{Results}

\section{SNP summary statistics}

Summary statistics for each of the 17 SNPs assayed for this study are presented in Table 2. Minor allele frequencies (MAFs) for all SNPs were between 0.05-0.41. Heterozygosity (i.e. the proportion of heterozygous individuals) for all 17 SNPs ranged between 0.09-0.46, with a mean of 0.31 across all SNPs. Four SNPs displayed deviations from Hardy-Weinberg proportions $(P \leq 0.01)$ and in each case this was due to an excess of homozygotes, presumably due to sampling error. Within-gene and within-gene cluster $r^{2}$ measures of LD (Additional File 2) ranged between 0.001 (for two pairwise SNP combinations within the PEG3 imprinted domain) and 1.000 (for the single pairwise SNP combination with the ZIM2 gene).

\section{A summary of SNP genotype-phenotype associations}

Genotype association analysis identified nine SNPs that were associated $(P \leq 0.05)$ with genetic merit for at least one of the performance traits assessed, while two SNPsthe single SNP in the PHLDA2 (rs42194502) gene and one in the TSPAN32 gene (rs42637579)-were not significantly associated with any of the traits analysed. The remaining six SNPs tended to be associated $(P \leq 0.10)$ with at least one of the traits analysed. The genotypephenotype associations detected in this study are discussed in further detail below.

\section{Associations with milk traits, somatic cell counts, calving traits and fertility traits}

Allele substitution effects for milk traits, somatic cell counts and perinatal mortality are detailed in Table 3. None of the SNPs analysed were significantly associated with milk yield or milk fat yield (results not shown). A-to-G allele substitutions at the rs42575474 (ZNF215 gene) and RASGRF1_p.C25039690T SNPs were both associated $(P \leq 0.05)$ with a reduction in milk protein percentage. The A-to-G allele substitution at the RASGRF1_p.C25039690T SNP was also associated $(P \leq$ $0.05)$ with an increase in somatic cell score, while the A-to-G substitution at the rs42575474 SNP (ZNF215 gene) tended to be associated $(P \leq 0.10)$ with an increase in somatic cell score. A tendency to be associated $(P \leq 0.10)$ with milk traits was also observed at four other SNPs: the C-to-T allele substitution at the rs42940187 SNP (CALCR gene) with increased milk fat yield $(+0.819 \mathrm{~kg}$, standard error $[\mathrm{SE}] \pm 0.466 \mathrm{~kg})$ and no other SNPs were associated or tended to be associated with this trait, the $r 443375833$ SNP (GRB10 gene) with milk protein yield, the $r 542637578$ (TSPAN32 gene) SNP with milk fat percentage and milk protein percentage and the rs42575466 (ZNF215 gene) SNPs with milk protein percentage.

Three SNPs (rs17871322 [PEG3 gene], rs41899913 [ZIM2 gene], and rs41899911 [ZIM2 gene]) all within the PEG3 imprinted domain on BTA18 were associated $(P \leq 0.05)$ with perinatal mortality, while the $r s 41899915$ SNP (ZIM2) tended to be associated $(P \leq 0.10)$ with this trait; none of the SNPs analysed were associated with calf survival. The low pairwise $r^{2}$ values of LD between the $r s 41899913$ and $r s 17871322$ SNPs $\left(r^{2}=0.095\right)$ and the $r s 41899911$ and $r s 17871322$ SNPs $\left(r^{2}=0.116\right)$ suggests that some of the observed associations with perinatal mortality and these PEG3 gene cluster SNPs are independent. In addition, the $r s 17871322$ SNP within the PEG3 gene was the only SNP associated $(P \leq 0.05)$ with both direct calving difficulty (i.e. maternal calving difficulty due to the size of the calf-a G-to-A allele substitution at this locus results in an increase in direct calving difficulty of $0.280 \%$; $\mathrm{SE} \pm 0.124$ ) and maternal calf difficulty (i.e. a function of maternal pelvic width-a G-to-A allele substitution at this locus results in an decrease in calving difficulty of $0.289 \%$; $\mathrm{SE} \pm 0.144$ ). The 
Table 3 SNP associations with milk traits, somatic cell score and calf perinatal mortality

\begin{tabular}{|c|c|c|c|c|c|c|c|}
\hline SNP & $\begin{array}{l}\text { Gene/ } \\
\text { BTA }\end{array}$ & $\begin{array}{l}\text { Allele } \\
\text { substitution }\end{array}$ & $\begin{array}{l}\text { Milk protein } \\
\text { yield }(\mathrm{kg})\end{array}$ & $\begin{array}{l}\text { Milk fat } \\
\text { percentage }{ }^{1} \\
(\times 100)\end{array}$ & $\begin{array}{l}\text { Milk protein } \\
\text { percentage }^{1}(\times 100)\end{array}$ & $\begin{array}{l}\text { Somatic cell count }{ }^{1} \\
\text { (units } \times 100)\end{array}$ & $\begin{array}{l}\text { Calf perinatal } \\
\text { mortality }{ }^{1}(\% \times 100)\end{array}$ \\
\hline rs42940189 & $\begin{array}{l}\text { CALCR/ } \\
\text { BTA4 }\end{array}$ & $A \rightarrow G$ & $\begin{array}{l}0.073 \\
(0.424)\end{array}$ & $\begin{array}{l}-1.31 \\
(1.15)\end{array}$ & $\begin{array}{l}-0.47 \\
(0.56)\end{array}$ & $\begin{array}{l}-0.64 \\
(0.92) \\
0.0 .()\end{array}$ & $\begin{array}{l}3.67 \\
(14.79)\end{array}$ \\
\hline rs42940187 & $\begin{array}{l}\text { CALCR/ } \\
\text { BTA4 }\end{array}$ & $C \rightarrow T$ & $\begin{array}{l}0.131 \\
(0.365)\end{array}$ & $\begin{array}{l}1.17 \\
(0.99)\end{array}$ & $\begin{array}{l}-0.07 \\
(0.48)\end{array}$ & $\begin{array}{l}0.78 \\
(0.79)\end{array}$ & $\begin{array}{l}-9.05 \\
(12.35)\end{array}$ \\
\hline $\begin{array}{l}\text { GRB10_p. } \\
\text { A5394141C }\end{array}$ & $\begin{array}{l}\text { GRB10/ } \\
\text { BTA4 }\end{array}$ & $A \rightarrow C$ & $\begin{array}{l}0.103 \\
(0.605)\end{array}$ & $\begin{array}{l}-1.12 \\
(1.64)\end{array}$ & $\begin{array}{l}-1.03 \\
(0.80)\end{array}$ & $\begin{array}{l}0.43 \\
(1.31)\end{array}$ & $\begin{array}{l}-3.88 \\
(21.17)\end{array}$ \\
\hline rs43375833 & $\begin{array}{l}\text { GRB10/ } \\
\text { BTA4 }\end{array}$ & $C \rightarrow \top$ & $\begin{array}{l}-0.522^{\dagger} \\
(0.280)\end{array}$ & $\begin{array}{l}0.43 \\
(0.76)\end{array}$ & $\begin{array}{l}-0.08 \\
(0.37)\end{array}$ & $\begin{array}{l}0.04 \\
(0.61)\end{array}$ & $\begin{array}{l}7.99 \\
(9.47)\end{array}$ \\
\hline rs 42575466 & $\begin{array}{l}\text { ZNF215/ } \\
\text { BTA15 }\end{array}$ & $\mathrm{A} \rightarrow \mathrm{G}$ & $\begin{array}{l}0.175 \\
(0.575)\end{array}$ & $\begin{array}{l}-0.73 \\
(1.55)\end{array}$ & $\begin{array}{l}-1.42^{\dagger} \\
(0.75)\end{array}$ & $\begin{array}{l}0.28 \\
(1.25)\end{array}$ & $\begin{array}{l}-4.84 \\
(19.26)\end{array}$ \\
\hline rs 42575474 & $\begin{array}{l}\text { ZNF215/ } \\
\text { BTA15 }\end{array}$ & $\mathrm{A} \rightarrow \mathrm{G}$ & $\begin{array}{l}0.009 \\
(0.284)\end{array}$ & $\begin{array}{l}-1.23 \\
(0.77)\end{array}$ & $\begin{array}{l}-0.77^{*} \\
(0.37)\end{array}$ & $\begin{array}{l}1.13^{\dagger} \\
(0.61)\end{array}$ & $\begin{array}{l}11.69 \\
(9.28)\end{array}$ \\
\hline $\begin{array}{l}\text { PEG3_p. } \\
\text { A64370595G }\end{array}$ & $\begin{array}{l}\text { PEG3/ } \\
\text { BTA18 }\end{array}$ & $A \rightarrow G$ & $\begin{array}{l}0.127 \\
(0.276)\end{array}$ & $\begin{array}{l}0.14 \\
(0.75)\end{array}$ & $\begin{array}{l}-0.20 \\
(0.37)\end{array}$ & $\begin{array}{l}-0.77 \\
(0.61)\end{array}$ & $\begin{array}{l}0.09 \\
(9.28)\end{array}$ \\
\hline $\begin{array}{l}\text { PEG3_p. } \\
\text { C64367437T }\end{array}$ & $\begin{array}{l}\text { PEG3/ } \\
\text { BTA18 }\end{array}$ & $C \rightarrow T$ & $\begin{array}{l}-0.025 \\
(0.269)\end{array}$ & $\begin{array}{l}-0.03 \\
(0.73)\end{array}$ & $\begin{array}{l}0.07 \\
(0.35)\end{array}$ & $\begin{array}{l}0.78 \\
(0.58)\end{array}$ & $\begin{array}{l}0.86 \\
(9.35)\end{array}$ \\
\hline rs 17871322 & $\begin{array}{l}\text { PEG3/ } \\
\text { BTA18 }\end{array}$ & $A \rightarrow G$ & $\begin{array}{l}0.031 \\
(0.278)\end{array}$ & $\begin{array}{l}0.02 \\
(0.75)\end{array}$ & $\begin{array}{l}0.10 \\
(0.37)\end{array}$ & $\begin{array}{l}-0.72 \\
(0.60)\end{array}$ & $\begin{array}{l}-20.15^{*} \\
(9.61)\end{array}$ \\
\hline rs41899915 & $\begin{array}{l}\text { ZIM2/ } \\
\text { BTA18 }\end{array}$ & $C \rightarrow G$ & $\begin{array}{l}0.031 \\
(0.325)\end{array}$ & $\begin{array}{l}0.71 \\
(0.88)\end{array}$ & $\begin{array}{l}-0.04 \\
(0.43)\end{array}$ & $\begin{array}{l}-1.01 \\
(0.71)\end{array}$ & $\begin{array}{l}20.64^{\dagger} \\
(11.32)\end{array}$ \\
\hline rs41899913 & $\begin{array}{l}\text { ZIM2/ } \\
\text { BTA18 }\end{array}$ & $C \rightarrow G$ & $\begin{array}{l}0.303 \\
(0.342)\end{array}$ & $\begin{array}{l}-0.59 \\
(0.92)\end{array}$ & $\begin{array}{l}0.03 \\
(0.45)\end{array}$ & $\begin{array}{l}0.37 \\
(0.75)\end{array}$ & $\begin{array}{l}-25.22^{*} \\
(12.80)\end{array}$ \\
\hline rs41899911 & $\begin{array}{l}\text { ZIM2/ } \\
\text { BTA18 }\end{array}$ & $C \rightarrow T$ & $\begin{array}{l}0.026 \\
(0.326)\end{array}$ & $\begin{array}{l}0.76 \\
(0.88)\end{array}$ & $\begin{array}{l}-0.03 \\
(0.43)\end{array}$ & $\begin{array}{l}-0.97 \\
(0.71)\end{array}$ & $\begin{array}{l}21.82^{*} \\
(10.97)\end{array}$ \\
\hline rs41899910 & $\begin{array}{l}\text { ZIM2/ } \\
\text { BTA18 }\end{array}$ & $C \rightarrow T$ & $\begin{array}{l}-0.267 \\
(0.293)\end{array}$ & $\begin{array}{l}-0.03 \\
(0.79)\end{array}$ & $\begin{array}{l}-0.13 \\
(0.39)\end{array}$ & $\begin{array}{l}0.05 \\
(0.64)\end{array}$ & $\begin{array}{l}-2.33 \\
(9.92)\end{array}$ \\
\hline $\begin{array}{l}\text { RASGRF1_p. } \\
\text { C25039690T }\end{array}$ & $\begin{array}{l}\text { RASGRF1/ } \\
\text { BTA21 }\end{array}$ & $A \rightarrow G$ & $\begin{array}{l}-0.104 \\
(0.255)\end{array}$ & $\begin{array}{l}-0.85 \\
(0.69)\end{array}$ & $\begin{array}{l}-0.70^{*} \\
(0.34)\end{array}$ & $\begin{array}{l}1.29^{*} \\
(0.55)\end{array}$ & $\begin{array}{l}1.55 \\
(8.55)\end{array}$ \\
\hline rs42194502 & $\begin{array}{l}\text { PHLDA2/ } \\
\text { BTA29 }\end{array}$ & $\mathrm{A} \rightarrow \mathrm{T}$ & $\begin{array}{l}0.087 \\
(0.413)\end{array}$ & $\begin{array}{l}0.64 \\
(1.12)\end{array}$ & $\begin{array}{l}-0.39 \\
(0.54)\end{array}$ & $\begin{array}{l}-0.40 \\
(0.89)\end{array}$ & $\begin{array}{l}24.19 \\
(15.76)\end{array}$ \\
\hline rs42637579 & $\begin{array}{l}\text { TSPAN321 } \\
\text { BTA29 }\end{array}$ & $A \rightarrow G$ & $\begin{array}{l}0.078 \\
(0.268)\end{array}$ & $\begin{array}{l}-0.86 \\
(0.72)\end{array}$ & $\begin{array}{l}-0.33 \\
(0.35)\end{array}$ & $\begin{array}{l}0.35 \\
(0.58)\end{array}$ & $\begin{array}{l}-12.12 \\
(9.24)\end{array}$ \\
\hline rs42637578 & $\begin{array}{l}\text { TSPAN32I } \\
\text { BTA29 }\end{array}$ & $C \rightarrow T$ & $\begin{array}{l}-0.776 \\
(0.652)\end{array}$ & $\begin{array}{l}-2.32^{\dagger} \\
(1.39)\end{array}$ & $\begin{array}{l}-1.20^{\dagger} \\
(0.67)\end{array}$ & $\begin{array}{l}-0.83 \\
(1.11)\end{array}$ & $\begin{array}{l}-29.91^{\dagger} \\
(15.55)\end{array}$ \\
\hline
\end{tabular}

Standard errors for each trait are shown in parentheses. Levels of significance: ${ }^{\dagger} P \leq 0.10 ;{ }^{*} P \leq 0.05 ;{ }^{* *} P \leq 0.01$. ${ }^{1} \mathrm{~A}$ value of 1 prior to multiplication by 100 equates to 1 percentage unit.

rs17871322 SNP was also the only analysed SNP to be associated $(P \leq 0.05)$ with gestation length (an A-to-G allele substitution at this locus results in a decrease in gestation length of 0.154 days; $\mathrm{SE} \pm 0.078$ ). Collectively, these data point towards the PEG3 imprinted domain having a role in directing neonatal development. Finally, the T-to-C allele substitution at the rs42940187 SNP (CALCR gene) was negatively associated $(P \leq 0.05)$ with calving interval (-0.664 days; $S E \pm 0.338)$ and was the only SNP to be significantly associated with this trait.

\section{Associations with carcass traits, fat deposition, body conformation and growth-related traits}

The allele substitution effects associated with carcass traits, fat deposition on the live animal traits (angularity and body condition scores), body conformation traits and growth-related traits are detailed in Tables 4 and 5 . Five SNPs ( $r s 42940187$ [CALCR gene], GRB10_p. A5394141C, rs42575466 [ZNF215 gene], rs42575474 [ZNF215 gene], and rs41899913 [ZIM2 gene]) were associated $(P \leq 0.05)$ with angularity, while two SNPs (rs42940187 [CALCR1 gene] and rs43375833 [GRB10 gene]) were also associated $(P \leq 0.05)$ with body condition score. Cow angularity and body condition score are genetically similar yet opposite traits and are subjective assessments of the subcutaneous fat deposits on a live animal [51]; lower angularity and greater body condition score indicates increased fat deposits.

Five SNPs were associated $(P \leq 0.05)$ with at least one of the carcass traits or animal growth traits assessed. An A-to-G allele substitution at the rs42575474 (ZNF215 gene) SNP was associated with gains in progeny carcass 
Table 4 SNP associations with carcass traits and fat deposition traits

\begin{tabular}{|c|c|c|c|c|c|c|c|c|}
\hline$\overline{\text { SNP }}$ & $\begin{array}{l}\text { Gene/ } \\
\text { BTA }\end{array}$ & $\begin{array}{l}\text { Allele } \\
\text { substitution }\end{array}$ & $\begin{array}{l}\text { Culled cow } \\
\text { carcass weight } \\
\text { (kg) }\end{array}$ & $\begin{array}{l}\text { Progeny carcass } \\
\text { weight }(\mathrm{kg})\end{array}$ & $\begin{array}{l}\text { Progeny carcass } \\
\text { conformation }^{1}\end{array}$ & $\begin{array}{l}\text { Progeny } \\
\text { carcass fat }^{1}\end{array}$ & Angularity $^{2}$ & $\begin{array}{l}\text { Body } \\
\text { condition } \\
\text { score }^{2}\end{array}$ \\
\hline rs42940189 & $\begin{array}{l}\text { CALCR/ } \\
\text { BTA4 }\end{array}$ & $A \rightarrow G$ & $\begin{array}{l}-0.880 \\
(0.965)\end{array}$ & $\begin{array}{l}-0.901 \\
(0.747)\end{array}$ & $\begin{array}{l}-0.030 \\
(0.031)\end{array}$ & $\begin{array}{l}-0.014 \\
(0.027)\end{array}$ & $\begin{array}{l}-0.154 \\
(0.156)\end{array}$ & $\begin{array}{l}0.104 \\
(0.125)\end{array}$ \\
\hline rs42940187 & $\begin{array}{l}\text { CALCR/ } \\
\text { BTA4 }\end{array}$ & $C \rightarrow T$ & $\begin{array}{l}0.738 \\
(0.840)\end{array}$ & $\begin{array}{l}0.877 \\
(0.650)\end{array}$ & $\begin{array}{l}0.012 \\
(0.027)\end{array}$ & $\begin{array}{l}-0.002 \\
(0.024)\end{array}$ & $\begin{array}{l}0.294^{*} \\
(0.129)\end{array}$ & $\begin{array}{l}-0.239^{*} \\
(0.103)\end{array}$ \\
\hline $\begin{array}{l}\text { GRB10_p. } \\
\text { A5394141C }\end{array}$ & $\begin{array}{l}\text { GRB10/ } \\
\text { BTA4 }\end{array}$ & $A \rightarrow C$ & $\begin{array}{l}-2.044 \\
(1.529)\end{array}$ & $\begin{array}{l}-0.453 \\
(1.191)\end{array}$ & $\begin{array}{l}0.004 \\
(0.049)\end{array}$ & $\begin{array}{l}0.071^{\dagger} \\
(0.043)\end{array}$ & $\begin{array}{l}0.435^{*} \\
(0.216)\end{array}$ & $\begin{array}{l}-0.052 \\
(0.171)\end{array}$ \\
\hline rs43375833 & $\begin{array}{l}\text { GRB10/ } \\
\text { BTA4 }\end{array}$ & $C \rightarrow T$ & $\begin{array}{l}-0.333 \\
(0.641)\end{array}$ & $\begin{array}{l}0.623 \\
(0.498)\end{array}$ & $\begin{array}{l}0.047^{*} \\
(0.021)\end{array}$ & $\begin{array}{l}0.002 \\
(0.018)\end{array}$ & $\begin{array}{l}-0.113 \\
(0.097)\end{array}$ & $\begin{array}{l}0.171^{*} \\
(0.078)\end{array}$ \\
\hline rs 42575466 & $\begin{array}{l}\text { ZNF215/ } \\
\text { BTA15 }\end{array}$ & $\mathrm{A} \rightarrow \mathrm{G}$ & $\begin{array}{l}2.118 \\
(1.294)\end{array}$ & $\begin{array}{l}1.394 \\
(0.996)\end{array}$ & $\begin{array}{l}-0.071^{\dagger} \\
(0.042)\end{array}$ & $\begin{array}{l}-0.020 \\
(0.037)\end{array}$ & $\begin{array}{l}0.506^{*} \\
(0.217)\end{array}$ & $\begin{array}{l}-0.180 \\
(2.584)\end{array}$ \\
\hline rs 42575474 & $\begin{array}{l}\text { ZNF215/ } \\
\text { BTA15 }\end{array}$ & $\mathrm{A} \rightarrow \mathrm{G}$ & $\begin{array}{l}1.882^{* *} \\
(0.648)\end{array}$ & $\begin{array}{l}1.168^{*} \\
(0.503)\end{array}$ & $\begin{array}{l}0.0174 \\
(0.021)\end{array}$ & $\begin{array}{l}-0.030^{\dagger} \\
(0.018)\end{array}$ & $\begin{array}{l}0.290^{* *} \\
(0.095)\end{array}$ & $\begin{array}{l}1.805 \\
(1.183)\end{array}$ \\
\hline $\begin{array}{l}\text { PEG3_p. } \\
\text { A64370595G }\end{array}$ & $\begin{array}{l}\text { PEG3/ } \\
\text { BTA18 }\end{array}$ & $\mathrm{A} \rightarrow \mathrm{G}$ & $\begin{array}{l}-0.065 \\
(0.644)\end{array}$ & $\begin{array}{l}-0.257 \\
(0.500)\end{array}$ & $\begin{array}{l}0.006 \\
(0.021)\end{array}$ & $\begin{array}{l}-0.030^{\dagger} \\
(0.018)\end{array}$ & $\begin{array}{l}0.009 \\
(0.091)\end{array}$ & $\begin{array}{l}-0.045 \\
(0.073)\end{array}$ \\
\hline $\begin{array}{l}\text { PEG3_p. } \\
\text { C64367437T }\end{array}$ & $\begin{array}{l}\text { PEG3/ } \\
\text { BTA18 }\end{array}$ & $C \rightarrow T$ & $\begin{array}{l}0.180 \\
(0.643)\end{array}$ & $\begin{array}{l}0.095 \\
(0.499)\end{array}$ & $\begin{array}{l}-0.024 \\
(0.021)\end{array}$ & $\begin{array}{l}0.023 \\
(0.018)\end{array}$ & $\begin{array}{l}0.028 \\
(0.090)\end{array}$ & $\begin{array}{l}0.018 \\
(1.145)\end{array}$ \\
\hline rs 17871322 & $\begin{array}{l}\text { PEG3/ } \\
\text { BTA18 }\end{array}$ & $A \rightarrow G$ & $\begin{array}{l}-0.624 \\
(0.648)\end{array}$ & $\begin{array}{l}-0.490 \\
(0.505)\end{array}$ & $\begin{array}{l}0.032 \\
(0.021)\end{array}$ & $\begin{array}{l}-0.005 \\
(0.018)\end{array}$ & $\begin{array}{l}-0.075 \\
(0.091)\end{array}$ & $\begin{array}{l}0.044 \\
(1.138)\end{array}$ \\
\hline rs41899915 & $\begin{array}{l}\text { ZIM2/ } \\
\text { BTA18 }\end{array}$ & $C \rightarrow G$ & $\begin{array}{l}0.104 \\
(0.767)\end{array}$ & $\begin{array}{l}-0.331 \\
(0.596)\end{array}$ & $\begin{array}{l}-0.020 \\
(0.025)\end{array}$ & $\begin{array}{l}-0.011 \\
(0.022)\end{array}$ & $\begin{array}{l}-0.081 \\
(0.106)\end{array}$ & $\begin{array}{l}0.987 \\
(1.295)\end{array}$ \\
\hline rs41899913 & $\begin{array}{l}\text { ZIM2/ } \\
\text { BTA18 }\end{array}$ & $C \rightarrow G$ & $\begin{array}{l}0.131 \\
(0.832)\end{array}$ & $\begin{array}{l}0.332 \\
(0.651)\end{array}$ & $\begin{array}{l}-0.013 \\
(0.027)\end{array}$ & $\begin{array}{l}0.006 \\
(0.024)\end{array}$ & $\begin{array}{l}0.244^{*} \\
(0.112)\end{array}$ & $\begin{array}{l}0.636 \\
(1.409)\end{array}$ \\
\hline rs41899911 & $\begin{array}{l}\text { ZIM2/ } \\
\text { BTA18 }\end{array}$ & $C \rightarrow T$ & $\begin{array}{l}0.120 \\
(0.766)\end{array}$ & $\begin{array}{l}-0.321 \\
(0.596)\end{array}$ & $\begin{array}{l}-0.024 \\
(0.025)\end{array}$ & $\begin{array}{l}-0.010 \\
(0.022)\end{array}$ & $\begin{array}{l}-0.059 \\
(0.106)\end{array}$ & $\begin{array}{l}0.946 \\
(1.291)\end{array}$ \\
\hline rs41899910 & $\begin{array}{l}\text { ZIM2/ } \\
\text { BTA18 }\end{array}$ & $C \rightarrow T$ & $\begin{array}{l}0.527 \\
(0.685)\end{array}$ & $\begin{array}{l}0.101 \\
(0.531)\end{array}$ & $\begin{array}{l}0.015 \\
(0.022)\end{array}$ & $\begin{array}{l}-0.005 \\
(0.019)\end{array}$ & $\begin{array}{l}0.121 \\
(0.096)\end{array}$ & $\begin{array}{l}-0.891 \\
(1.158)\end{array}$ \\
\hline $\begin{array}{l}\text { RASGRF1_p. } \\
\text { C25039690T }\end{array}$ & $\begin{array}{l}\text { RASGRF1/ } \\
\text { BTA21 }\end{array}$ & $\mathrm{A} \rightarrow \mathrm{G}$ & $\begin{array}{l}-0.375 \\
(0.584)\end{array}$ & $\begin{array}{l}0.414 \\
(0.459)\end{array}$ & $\begin{array}{l}0.035+ \\
(0.019)\end{array}$ & $\begin{array}{l}0.003 \\
(0.017)\end{array}$ & $\begin{array}{l}-0.154^{\dagger} \\
(0.085)\end{array}$ & $\begin{array}{l}-1.540 \\
(1.056)\end{array}$ \\
\hline rs42194502 & $\begin{array}{l}\text { PHLDA2/ } \\
\text { BTA29 }\end{array}$ & $A \rightarrow T$ & $\begin{array}{l}0.064 \\
(0.975)\end{array}$ & $\begin{array}{l}-0.322 \\
(0.762)\end{array}$ & $\begin{array}{l}-0.018 \\
(0.032)\end{array}$ & $\begin{array}{l}0.007 \\
(0.027)\end{array}$ & $\begin{array}{l}0.026 \\
(0.135)\end{array}$ & $\begin{array}{l}0.178 \\
(1.678)\end{array}$ \\
\hline rs42637579 & $\begin{array}{l}\text { TSPAN32/ } \\
\text { BTA29 }\end{array}$ & $A \rightarrow G$ & $\begin{array}{l}-0.076 \\
(0.642)\end{array}$ & $\begin{array}{l}-0.504 \\
(0.504)\end{array}$ & $\begin{array}{l}-0.023 \\
(0.021)\end{array}$ & $\begin{array}{l}0.015 \\
(0.018)\end{array}$ & $\begin{array}{l}0.100 \\
(0.090)\end{array}$ & $\begin{array}{l}0.499 \\
(1.130)\end{array}$ \\
\hline rs42637578 & $\begin{array}{l}\text { TSPAN32I } \\
\text { BTA29 }\end{array}$ & $C \rightarrow T$ & $\begin{array}{l}1.918^{\dagger} \\
(1.147)\end{array}$ & $\begin{array}{l}0.757 \\
(0.899)\end{array}$ & $\begin{array}{l}0.031 \\
(0.038)\end{array}$ & $\begin{array}{l}-0.054 \\
(0.039)\end{array}$ & $\begin{array}{l}-0.022 \\
(0.172)\end{array}$ & $\begin{array}{l}-1.055 \\
(2.076)\end{array}$ \\
\hline
\end{tabular}

Standard errors for each trait are shown in parentheses. Levels of significance: ${ }^{\dagger} P \leq 0.10$; $P \leq 0.05 ;{ }^{*} P \leq 0.01$. Progeny carcass fat score and progeny carcass conformation score are shown on a scale of 1.00 (low) to 15.00 (high) according to Hickey et al. [97]. ${ }^{1}$ A value of 1 equates to 1 percentage unit. ${ }^{2}$ Expressed in genetic standard deviations.

weight $(P \leq 0.05)$ and culled cow carcass weight $(P \leq$ $0.01)$; no other SNPs were associated with these traits (results not shown). Similarly, the A-to-G substitution at this locus was also associated with greater body depth $(P \leq 0.01)$ and taller animals, as illustrated with associations with animal stature $(P \leq 0.01)$ with wider rumps $(P \leq 0.01)$, suggesting that this gene plays a role in promoting growth. The other genotyped ZNF215 SNP (rs42575466) also displayed an association $(P \leq 0.05)$ with animal stature. Both ZNF215 SNPs displayed low $r^{2}$ values of LD $\left(r^{2}=0.114\right)$ suggesting that the association of these SNPs with animal growth are independent and may indicate the presence of ZNF215 haplotypes that are associated with animal growth.

The remaining three SNPs showing associations $(P \leq$ 0.05 ) with growth-related traits were the GRB10 gene rs43375833 SNP (progeny carcass conformation and rump angle), the PEG3 gene rs17871322 SNP (body depth and animal stature), and the ZIM2 gene rs41899913 SNP (animal stature). In addition, phenotypic associations with at least one of the carcass or growth-related traits examined approached statistical significance $(P \leq 0.10)$ at several SNP loci: three SNPs with progeny carcass fat (GRB10_p. A5394141C, rs42575474 [ZNF215 gene] and PEG3_p. $A 64370595 G)$; one SNP with culled cow carcass weight (rs42637578 [TSPAN32 gene]); three SNPs with rump width (GRB10_p.A5394141C, PEG3_p.A64370595G, rs17871322 [PEG3 gene]); one SNP with animal stature (GRB10_p.A5394141C); and two SNPs with body depth (PEG3_p.C64367437T, rs41899913 [ZIM2 gene]). None of the genotyped SNPs were associated with chest width (results not shown). 
Table 5 SNP associations with body conformation traits and growth-related traits

\begin{tabular}{|c|c|c|c|c|c|c|}
\hline SNP & Gene/BTA & Allele substitution & Body depth $^{1}$ & Rump angle $^{1}$ & Rump width $^{1}$ & Stature $^{1}$ \\
\hline rs42940189 & CALCR/BTA4 & $A \rightarrow G$ & $\begin{array}{l}-0.240^{\dagger} \\
(0.140)\end{array}$ & $\begin{array}{l}0.136 \\
(0.149)\end{array}$ & $\begin{array}{l}0.062 \\
(0.157)\end{array}$ & $\begin{array}{l}-0.169 \\
(0.151)\end{array}$ \\
\hline rs42940187 & CALCR/BTA4 & $C \rightarrow T$ & $\begin{array}{l}0.161 \\
(0.116)\end{array}$ & $\begin{array}{l}-0.050 \\
(0.125)\end{array}$ & $\begin{array}{l}-0.151 \\
(0.130)\end{array}$ & $\begin{array}{l}0.169 \\
(0.124)\end{array}$ \\
\hline GRB10_p.A5394141C & GRB10/BTA4 & $A \rightarrow C$ & $\begin{array}{l}0.166 \\
(0.193)\end{array}$ & $\begin{array}{l}0.191 \\
(0.198)\end{array}$ & $\begin{array}{l}0.352^{\dagger} \\
(0.206)\end{array}$ & $\begin{array}{l}0.371^{\dagger} \\
(0.200)\end{array}$ \\
\hline rs43375833 & GRB10/BTA4 & $C \rightarrow T$ & $\begin{array}{l}-0.001 \\
(0.088)\end{array}$ & $\begin{array}{l}-0.239^{*} \\
(0.093)\end{array}$ & $\begin{array}{l}0.067 \\
(0.097)\end{array}$ & $\begin{array}{l}-0.033 \\
(0.094)\end{array}$ \\
\hline rs 42575466 & ZNF215/BTA15 & $A \rightarrow G$ & $\begin{array}{l}0.280 \\
(0.195)\end{array}$ & $\begin{array}{l}0.075 \\
(0.200)\end{array}$ & $\begin{array}{l}0.173 \\
(0.206)\end{array}$ & $\begin{array}{l}0.479^{*} \\
(0.202)\end{array}$ \\
\hline rs42575474 & ZNF215/BTA15 & $\mathrm{A} \rightarrow \mathrm{G}$ & $\begin{array}{l}0.245^{* *} \\
(0.086)\end{array}$ & $\begin{array}{l}-0.018 \\
(0.091)\end{array}$ & $\begin{array}{l}0.293^{* *} \\
(0.093)\end{array}$ & $\begin{array}{l}0.302^{* *} \\
(0.092)\end{array}$ \\
\hline PEG3_p.A64370595G & PEG3/BTA18 & $A \rightarrow G$ & $\begin{array}{l}-0.106 \\
(0.083)\end{array}$ & $\begin{array}{l}0.109 \\
(0.087)\end{array}$ & $\begin{array}{l}-0.156^{\dagger} \\
(0.092)\end{array}$ & $\begin{array}{l}-0.082 \\
(0.088)\end{array}$ \\
\hline PEG3_p.C64367437T & PEG3/BTA18 & $C \rightarrow T$ & $\begin{array}{l}0.152^{\dagger} \\
(0.081)\end{array}$ & $\begin{array}{l}-0.053 \\
(0.086)\end{array}$ & $\begin{array}{l}0.140 \\
(0.090)\end{array}$ & $\begin{array}{l}0.111 \\
(0.087)\end{array}$ \\
\hline rs17871322 & PEG3/BTA18 & $A \rightarrow G$ & $\begin{array}{l}-0.180^{*} \\
(0.083)\end{array}$ & $\begin{array}{l}0.068 \\
(0.088)\end{array}$ & $\begin{array}{l}-0.168^{\dagger} \\
(0.092)\end{array}$ & $\begin{array}{l}-0.212^{*} \\
(0.088)\end{array}$ \\
\hline rs41899915 & ZIM2/BTA18 & $\mathrm{C} \rightarrow \mathrm{G}$ & $\begin{array}{l}-0.101 \\
(0.096)\end{array}$ & $\begin{array}{l}0.119 \\
(0.101)\end{array}$ & $\begin{array}{l}-0.046 \\
(0.105)\end{array}$ & $\begin{array}{l}-0.113 \\
(0.102)\end{array}$ \\
\hline rs41899913 & ZIM2/BTA18 & $\mathrm{C} \rightarrow \mathrm{G}$ & $\begin{array}{l}0.183^{\dagger} \\
(0.101)\end{array}$ & $\begin{array}{l}-0.114 \\
(0.107)\end{array}$ & $\begin{array}{l}0.154 \\
(0.112)\end{array}$ & $\begin{array}{l}0.250^{*} \\
(0.108)\end{array}$ \\
\hline rs41899911 & ZIM2/BTA18 & $C \rightarrow T$ & $\begin{array}{l}-0.084 \\
(0.096)\end{array}$ & $\begin{array}{l}0.107 \\
(0.101)\end{array}$ & $\begin{array}{l}-0.031 \\
(0.106)\end{array}$ & $\begin{array}{l}-0.088 \\
(0.103)\end{array}$ \\
\hline rs41899910 & ZIM2/BTA18 & $C \rightarrow T$ & $\begin{array}{l}0.123 \\
(0.087)\end{array}$ & $\begin{array}{l}-0.148 \\
(0.091)\end{array}$ & $\begin{array}{l}0.048 \\
(0.095)\end{array}$ & $\begin{array}{l}0.120 \\
(0.093)\end{array}$ \\
\hline RASGRF1_p.C25039690T & RASGRF1/BTA21 & $\mathrm{A} \rightarrow \mathrm{G}$ & $\begin{array}{l}-0.066 \\
(0.076)\end{array}$ & $\begin{array}{l}0.012 \\
(0.0801\end{array}$ & $\begin{array}{l}-0.075 \\
(0.084)\end{array}$ & $\begin{array}{l}-0.096 \\
(0.081)\end{array}$ \\
\hline rs42194502 & PHLDA2/BTA29 & $A \rightarrow T$ & $\begin{array}{l}-0.131 \\
(0.122)\end{array}$ & $\begin{array}{l}0.210 \\
(0.128)\end{array}$ & $\begin{array}{l}-0.081 \\
(0.135)\end{array}$ & $\begin{array}{l}0.001 \\
(0.130)\end{array}$ \\
\hline rs42637579 & TSPAN32/BTA29 & $\mathrm{A} \rightarrow \mathrm{G}$ & $\begin{array}{l}0.027 \\
(0.082)\end{array}$ & $\begin{array}{l}-0.008 \\
(0.085)\end{array}$ & $\begin{array}{l}0.044 \\
(0.089)\end{array}$ & $\begin{array}{l}0.075 \\
(0.087)\end{array}$ \\
\hline rs42637578 & TSPAN32/BTA29 & $C \rightarrow T$ & $\begin{array}{l}0.062 \\
(0.156)\end{array}$ & $\begin{array}{l}0.124 \\
(0.161)\end{array}$ & $\begin{array}{l}-0.150 \\
(0.170)\end{array}$ & $\begin{array}{l}0.079 \\
(0.165)\end{array}$ \\
\hline
\end{tabular}

Standard errors for each trait are shown in parentheses. Levels of significance: ${ }^{\dagger} P \leq 0.10 ;{ }^{*} P \leq 0.05 ;{ }^{* *} P \leq 0.01 .{ }^{1}$ Expressed in genetic standard deviations.

\section{Discussion}

Associations between SNPs in candidate bovine imprinted genes and performance traits

The recent availability of whole genome sequences has highlighted the wealth of DNA sequence variation contained within mammalian genomes, the vast majority of which exists as SNPs. The abundance of these genetic polymorphisms coupled with their ease of detection (via DNA sequencing) and ease-of-genotyping has resulted in their adoption as the marker of choice for genotypephenotype association analyses in livestock genetic studies [5]. Indeed, the recent advent of high-throughput SNP genotyping platforms for livestock, such as the Illumina BovineSNP50 assay [4], has provided animal geneticists with vast quantities of data for association studies performed at a genome-wide level. However, a perceived drawback of such genome-wide association (GWA) studies is the detection of false-positive associations between a SNP and a trait-of-interest which can confound studies, particularly when an associated SNP occurs in a gene or region of the genome displaying no obvious biological connection to the trait [52]. The detection and removal of spurious genotype-phenotype associations in GWA studies requires stringent statistical analysis involving the use of multiple-testing corrections; however, these can significantly reduce the number of associations reported in a study [53]. Furthermore, it is becoming increasingly recognised that correcting for multiple tests using conventional methods can be too restrictive in genotype-phenotype association studies resulting in SNPs displaying true associations being overlooked [54-56].

A commonly used method to circumvent the detection of spurious genotype-phenotype associations is the adoption of candidate gene strategies whereby SNPs are pre-selected for association analyses based on their location within or proximal to genes/loci known to have a molecular role in regulating a phenotype of interest 
[55,57-59]. Candidate gene approaches are also expected to reduce the number of false-negative genotype-phenotype associations (i.e. true associations that are erroneously rejected after rigorous statistical testing) that can also be generated in GWA studies [60,61]. Consequently, in the present study, we have adopted a candidate gene approach by analysing genotype-phenotype associations between SNPs in a panel of eight putatively imprinted bovine genes, one of which (PEG3) has been previously shown to be subject to genetic imprinting in cattle. The remaining seven genes have been shown to be imprinted in at least one other mammalian species and therefore may be imprinted in cattle based on the appreciable conservation of imprinting between orthologs from different species [36].

Mammalian imprinted genes have been shown to play a pivotal role in mediating growth and development. This suggests that imprinted genes may serve as candidate loci harbouring potentially important DNA sequence polymorphisms contributing to heritable variation in livestock performance traits-a hypothesis that is supported by a number of recent genotype-phenotype association studies performed in domestic livestock populations $[8,21,22,24,26,27,62]$. In this study, significant phenotypic associations $(P \leq 0.05)$ were detected between SNPs located proximal to or within six of the eight candidate bovine imprinted genes analysed-CALCR, GRB10, PEG3, RASGRF1, ZIM2, and ZNF215-and range of cattle performance traits; significant associations $(P \leq 0.05)$ were not observed between performance traits and SNPs within the PHLDA2 and TSPAN32 genes, although one SNP within the bovine TSPAN32 gene showed a tendency to be associated $(P \leq 0.10)$ with a number of the performance traits assessed.

It should be stated that in this study we applied a Bonferroni correction [63] in an attempt to minimise the incidence of false-positive associations. However, none of the adjusted genotype-phenotype association $P$-values were significant at the $P \leq 0.05$ level following this correction. Despite this, we believe that the uncorrected $P$-values $\leq 0.05$ for the genotype-phenotype associations reported in this candidate gene study are supported by the molecular biological functions of the candidate bovine imprinted genes analysed in this study.

For example, the $C A L C R$ gene encodes the calcitonin hormone receptor protein-a seven-transmembrane receptor located on the surface of osteoclasts to which calcitonin binds activating adenylate cyclase leading to the inhibition of osteoclastic bone resorption [64]. Previous studies have shown that SNPs in the porcine $C A L C R$ gene (whose imprinting status has yet to be defined, although preferential maternal expression of this gene has been reported in mouse brain tissue [65]) are associated with osteological development and growth performance in pigs $[66,67]$. Notably, no significant associations were observed between CALCR SNP genotypes and the more direct measures of animal growth in this study (i.e. body depth, chest width, rump width, rump angle and animal stature). However, the associations between both bovine CALCR SNPs analysed and angularity and body condition (both of which are measures of subcutaneous fat levels in live animals) as detected here does suggest that the CALCR locus encompasses or is located proximal to a QTL that contributes to inter-animal differences in bovine body conformation traits, especially those related to fat deposition.

GRB10 (or maternally expressed gene 1 [MEG1]) encodes an adapter protein which is known to interact with certain tyrosine kinase receptors, such as insulin receptors and insulin-like growth factor receptors [68], and acts to restrict foetal and placental growth during mammalian development [69]. This gene displays preferential maternal expression in the majority of mouse tissues examined to-date, with bi-allelic expression of the human GRB10 ortholog in corresponding human tissues and preferential paternal expression in human and mouse brain tissue [16]. Furthermore, perturbations of the imprinting status/gene dosage of GRB10, whereby the maternal copy of the GRB10 gene has been duplicated, has been shown to result in severe pre- and post-growth retardation in mice [70]. In this study, SNP genotype associations were observed between the bovine ortholog of this gene and angularity, body conditioning score and rump angle-traits related to animal development and growth. Based on these observations in cattle, it is possible that mutations in the GRB10 gene sequence alter the ability of the GRB10 protein in restricting foetal growth and development hence leading inter-individual differences in growth.

In mammals, both the PEG3 and ZIM2 genes form an imprinted gene cluster, a feature common to many imprinted genes [71]. The PEG3 gene cluster is located on chromosomes 7 and 19 in mouse and humans, respectively, and consists of at least five differentiallyimprinted genes, although analysis of this domain in human, mouse and cow has revealed some species-specific gene rearrangements [33]. The paternally expressed PEG3 gene encodes a Krüppel-type zinc finger protein that may play a role in transcriptional regulation [72-74]. Also, the murine ortholog of this gene, Peg3, has been shown to be critical in cellular and behavioural functions including cellular proliferation, apoptosis and nurturing behaviour $[40,75]$. The role of the maternally expressed ZIM2 gene is less well understood, but it has been shown to share at least seven upstream exons and a transcriptional start site with PEG3 in humans, suggesting some similarities for the function of the PEG3 
and ZIM2 gene products [39]. Two of the seven SNPs within the bovine PEG3 gene cluster were associated with animal stature, while one of these two SNPs was also associated with angularity, thus supporting a role in growth for this imprinted domain. In addition, three PEG3 domain SNPs were associated with perinatal mortality (with an additional two PEG3 domain SNPs displaying a tendency to be associated with this trait), while one PEG3 SNP was associated with gestation length, suggesting that the bovine PEG3 imprinted genes cluster underlies QTL for calf performance and fertility. Interestingly, aberrant methylation of the PEG3 gene (resulting in altered expression) has been observed in cases involving stillbirths and aborted foetuses in humans [76,77] and aborted cloned bovine embryos [78], suggesting that this gene has an important role in embryo and foetal viability and survival.

One bovine RASGRF1 SNP was analysed in this study and it displayed associations with milk protein percentage and was the only analysed SNP to be associated with somatic cell count. RASFGR1 encodes the Ras protein-specific guanine nucleotide releasing factor 1 protein, which has been shown to play a role in signal transduction and growth and development in mice [79]. Previous analyses performed by us identified this gene as being associated with growth traits in performancetested Limousin cattle [8]. Although no associations between the single analysed RASGRF1 SNP with growth were observed in the current study, the data presented here suggest that this gene may play a role in animal health as indicated by the association with somatic cell score-an often cited indicator of resistance to clinical and subclinical mastitis $[80,81]$. It is unclear how RASGRF1 associates with resistance/susceptibility to mastitis; however, previous work has shown that expression of RASGRF1 affects the function of the growth hormone-insulin-like growth factor 1 (GH-IGF-1) axis [79], which can modulate the inflammatory response to mastitis [82].

Finally, we detected associations with a number of growth-related traits and the bovine ZNF215 gene, which encodes an alternatively spliced zinc-finger DNA binding protein that is localised in the nucleus. Moreover, the ZNF215 protein has been shown to contain both a Krüppel-associated (KRAB) box and SCAN box (i.e. SRE-ZBP; CT-fin51; AW-1; Number 18) amino-acid structural domains found Krüppel-like $\mathrm{C}_{2} \mathrm{H}_{2}$ zinc finger DNA binding proteins, both of which act to repress transcription [83-85]. In humans, ZNF215 is preferentially expressed from the maternally inherited allele and maps to an imprinted gene cluster on human chromosome (HSA) 11p15.5, the genomic region associated with Beckwith-Wiedemann syndrome (BWS)-a genetic disorder characterised by a range of growth abnormalities, including gigantism [86]. It has been proposed that genetic rearrangements disrupt the normal functioning of the genes located within the imprinting domain on HSA11p15.5 (including ZNF215) resulting in the manifestation of the BWS phenotype; however, to-date, no functional ZNF215 mutations in BWS patients have been reported [83]. In the current study, two SNPs within the bovine ZNF215 ortholog were analysed for associations with performance traits. Both SNPs displayed associations with animal stature and angularity while one ZNF215 SNP ( $r$ 42575474) was associated with milk protein percentage, culled cow and progeny carcass weight, body depth and rump width. These data suggest that DNA sequence variation within the bovine imprinting domain orthologous to HSA11p15.5 located on BTA15 may also harbour important quantitative trait nucleotides (QTNs) that similarly influence animal growth. Indeed, it is possible that mutations in the ZNF215 gene may alter the binding affinity of the ZNF215 protein to DNA sequences and hence alter the expression of other genes involved in animal growth and developmental pathways.

With the exception of the CALCR rs42940189 SNP (a non-synonymous mutation resulting in the substitution of an asparagine amino acid to an aspartic amino acid, both of which are small polar amino acid residues, at amino acid position 116 of the CALCR protein), the ORF gene model location of the remaining 16 SNPs analysed in this study (i.e. two upstream, five intronic, five synonymous coding and four non-coding 3'UTR SNPs) does not immediately suggest that these polymorphisms are functional. However, previous studies have shown that non-coding SNPs can have a regulatory function by altering the efficiency of DNA binding proteins that modulate gene expression. For example, a single G-to-A substitution within a non-coding regulatory region of the $3^{\text {rd }}$ intron of the maternally imprinted porcine IGF2 gene has been shown to be the causal mutation for a QTL influencing muscle mass and fat deposition in pigs. It is postulated that the ' $\mathrm{A}$ ' allele at this locus prevents the binding of a transcriptional repressor protein to the IGF2 gene sequence; hence individuals inheriting a sire-derived 'A' allele at this SNP display increased muscle mass and reduced fat content due to over-expression of paternallyderived IGF2 mRNA [21,87].

3'UTR sequences of protein-coding mRNA transcripts have been shown to have an important function in regulating post-transcriptional process, such as the transportation of mRNA from the nucleus to cytoplasm, mRNA stability and the efficiency of protein translation $[88,89]$. This has led some authors to suggest that 3'UTR sequences harbour potentially important DNA sequence variants influencing phenotypes in mammals [90]. This 
assertion further supported by genetic data from livestock whereby 3'UTR SNPs have been shown to be associated with dairy performance traits in cattle [91,92]. However, while it is tempting to speculate that the noncoding SNPs displaying associations with performance traits in the current study are causal it is more likely that these SNPs are associated (through LD) with causal regulatory mutations (or set of mutations) located proximal to, or within, the genetic loci studied that have not yet been identified.

\section{Imprinted gene loci as candidates for performance traits in cattle}

Recent studies have discussed the evolutionary consequences and of parent-of-origin effects in animal breeding programmes and their effect on quantitative traits, especially where differences exist in the intensity of selection for sex-specific performance traits (e.g. muscling and milk traits) and male and female effective population sizes [29]. While previous genome scans for production traits studies using multi-generational structured livestock resource populations/pedigrees have incorporated the effect of imprinting and monoallelic expression $[19,22,93-96]$, the inclusion of parent-of-origin effects in our statistical analysis was not possible as the DNA samples used were derived solely from progeny-tested AI sires. Therefore, it is important to note that the analyses presented here may have reduced sensitivity to phenotypic effects for SNPs associated with imprinted genes.

Furthermore, imprinting is expected to affect the statistical models used for quantitative genetic analyses and animal breeding by causing differences between male and female breeding values and leading to deviations in additive and non-additive genetic effects. For example, in the case of phenotypes influenced by imprinted loci, offspring are expected to phenotypically resemble the parent from which the functional allele has been inherited-an observation that has particular importance in breeding strategies when favourable alleles occur at imprinted loci $[28,29]$. Notably, in the present study, two of the six genes displaying significant associations $(P \leq 0.05)$ with performance traits are inferred to be maternally expressed based on their imprinting status in other species (i.e. CALCR and ZNF215). As the association analyses presented here are based on phenotypic data from progeny-tested AI sires, this leads to the paradoxical observation-contrary to the imprinting modelthat variation in maternally expressed genes inherited from a sire are associated with progeny phenotypes. However, this can be resolved by noting the following: (1) that the genetic merit for each of traits examined here is calculated from many descendents across multiple generations (with female intermediaries); therefore, variation in sire-derived paternally imprinted genes could be associated with performance; and (2) that the SNPs associated with performance traits in this study may actually be in LD with causal variants at neighbouring loci.

\section{Conclusions}

The results presented here add to previous investigations performed by us and other groups suggesting that candidate imprinted genes contribute to many performance traits in cattle. These findings, together with the documented biological roles of these candidate imprinted genes suggest that these genes represent an important reservoir of molecular markers for future genetic improvement of dairy and beef cattle populations [18].

\section{Additional material}

Additional file 1: Descriptions of the performance traits assessed in the present study. This Microsoft Word file contains detailed

information for each of the phenotypic trait analysed as provided by the Irish Cattle Breeding Federation (ICBF) (http://www.icbf.com).

Additional file 2: Within-gene pairwise SNP linkage disequilibrium (LD) values. This Microsoft Excel file contains $D^{\prime}$ and $r^{2}$ measures of LD for each within-gene pairwise SNP combination.

\section{Acknowledgements}

This work was supported by Research Stimulus Grants from the Irish Department of Agriculture, Fisheries and Food (project numbers: RSF-06-406, RSF-06-0353 and RSF-06-0409) and Investigator Programme Grants from Science Foundation Ireland (SFI/01/F.1/B028; SFI/08/IN.1/B1931). MPM is supported by Science Foundation Ireland grant number 07/SRC/B1156. We also wish to thank the three anonymous reviewers for scientific insight in their critical evaluation of this manuscript.

\section{Author details}

${ }^{1}$ Animal Genomics Laboratory, UCD School of Agriculture, Food Science and Veterinary Medicine, University College Dublin, Belfield, Dublin 4, Ireland. ${ }^{2}$ Genetics and Biotechnology Laboratory, Department of Biochemistry, University College Cork, Cork, Ireland. ${ }^{3}$ Current address: Genetics and Biotechnology Laboratory, Centre for Chromosome Biology, National University of Ireland Galway, Ireland. ${ }^{4}$ Animal and Bioscience Research Department, Animal and Grassland Research and Innovation Centre, Teagasc, Fermoy, Co. Cork, Ireland. ${ }^{5}$ Animal and Bioscience Research Department, Animal and Grassland Research and Innovation Centre, Teagasc, Mellows Campus, Athenry, Co. Galway, Ireland. ${ }^{6}$ Irish Cattle Breeding Federation, Highfield House, Bandon, Co. Cork, Ireland. ${ }^{7}$ UCD Conway Institute of Biomolecular and Biomedical Research, University College Dublin, Belfield, Dublin 4, Ireland.

\section{Authors' contributions}

DAM, KMS and EWB performed laboratory work including validation of the SNPs analysed in this study, preparation of DNA samples for genotyping, data analysis and drafted the manuscript. DPB collected phenotypic data for the animals used in this study, performed statistical analyses of the genotypic and phenotypic data and contributed to the preparation of the manuscript. DJH and MPM extracted DNA from the semen samples used and also prepared samples for genotyping. RDE contributed to the collection and analysis of the phenotypic data used in this study. CS and DEM conceived the study, participated in its design and coordination and helped to draft the manuscript. All authors read and approved the final manuscript.

Received: 12 April 2010 Accepted: 13 October 2010 Published: 13 October 2010 


\section{References}

1. Kruglyak L, Nickerson DA: Variation is the spice of life. Nat Genet 2001, 27(3):234-236

2. Williams JL, Dunner S, Valentini A, Mazza R, Amarger V, Checa ML, Crisa A, Razzaq N, Delourme D, Grandjean F, et al: Discovery, characterization and validation of single nucleotide polymorphisms within 206 bovine genes that may be considered as candidate genes for beef production and quality. Anim Genet 2009, 40(4):486-491.

3. Elsik CG, Tellam RL, Worley KC, Gibbs RA, Muzny DM, Weinstock GM, Adelson DL, Eichler EE, Elnitski L, Guigo R, et al: The genome sequence of taurine cattle: a window to ruminant biology and evolution. Science 2009, 324(5926):522-528

4. Matukumalli LK, Lawley CT, Schnabel RD, Taylor JF, Allan MF, Heaton MP, O'Connell J, Moore SS, Smith TP, Sonstegard TS, et al: Development and characterization of a high density SNP genotyping assay for cattle. PLoS One 2009, 4(4):e5350.

5. Goddard ME, Hayes BJ: Mapping genes for complex traits in domestic animals and their use in breeding programmes. Nat Rev Genet 2009, 10(6):381-391.

6. Hu X, Gao Y, Feng C, Liu Q, Wang X, Du Z, Wang Q, Li N: Advanced technologies for genomic analysis in farm animals and its application for QTL mapping. Genetica 2009, 136(2):371-386.

7. Ron M, Weller Jl: From QTL to QTN identification in livestock-winning by points rather than knock-out: a review. Anim Genet 2007, 38(5):429-439.

8. Magee DA, Berkowicz EW, Sikora KM, Berry DP, Park SDE, Kelly AK, Sweeney T, Kenny DA, Evans RD, Wickham BW, et al: A catalogue of validated single nucleotide polymorphisms in bovine orthologs of mammalian imprinted genes and associations with beef production traits. Animal 2010.

9. Khatib $\mathrm{H}$ : Is it genomic imprinting or preferential expression? Bioessays 2007, 29(10):1022-1028.

10. Surani MA, Barton SC, Norris ML: Development of reconstituted mouse eggs suggests imprinting of the genome during gametogenesis. Nature 1984, 308(5959):548-550.

11. McGrath J, Solter D: Completion of mouse embryogenesis requires both the maternal and paternal genomes. Cell 1984, 37(1):179-183.

12. Dupont C, Armant DR, Brenner CA: Epigenetics: definition, mechanisms and clinical perspective. Semin Reprod Med 2009, 27(5):351-357.

13. Feil R: Epigenetic asymmetry in the zygote and mammalian development. Int J Dev Biol 2009, 53(2-3):191-201.

14. Jirtle RL: Geneimprint website. [http://www.geneimprint.com].

15. Williamson CM, Blake A, Thomas S, Beechey CV, Hancock J, Cattanach BM, Peters J: MRC Harwell, Oxfordshire. World Wide Web Site - Mouse Imprinting Data and References. [http://www.har.mrc.ac.uk/research/ genomic imprinting].

16. Morison IM, Paton CJ, Cleverley SD: The imprinted gene and parent-oforigin effect database. Nucleic Acids Res 2001, 29(1):275-276.

17. Nezer C, Moreau L, Brouwers B, Coppieters W, Detilleux J, Hanset R, Karim L, Kvasz A, Leroy P, Georges M: An imprinted QTL with major effect on muscle mass and fat deposition maps to the IGF2 locus in pigs. Nat Genet 1999, 21(2):155-156.

18. Ruvinsky A: Basics of gametic imprinting. J Anim Sci 1999, 77(2):228-237.

19. de Koning DJ, Rattink AP, Harlizius B, van Arendonk JA, Brascamp EW, Groenen MA: Genome-wide scan for body composition in pigs reveals important role of imprinting. Proc Natl Acad Sci USA 2000, 97(14):7947-7950.

20. Georges M, Charlier C, Cockett N: The callipyge locus: evidence for the trans interaction of reciprocally imprinted genes. Trends Genet 2003, 19(5):248-252.

21. Van Laere AS, Nguyen M, Braunschweig M, Nezer C, Collette C, Moreau L, Archibald AL, Haley CS, Buys N, Tally M, et al: A regulatory mutation in IGF2 causes a major QTL effect on muscle growth in the pig. Nature 2003, 425(6960):832-836.

22. Kim KS, Kim JJ, Dekkers JC, Rothschild MF: Polar overdominant inheritance of a DLK1 polymorphism is associated with growth and fatness in pigs. Mamm Genome 2004, 15(7):552-559.

23. Goodall JJ, Schmutz SM: IGF2 gene characterization and association with rib eye area in beef cattle. Anim Genet 2007, 38(2):154-161.

24. Cheng HC, Zhang FW, Jiang CD, Li FE, Xiong YZ, Deng CY: Isolation and imprinting analysis of the porcine $D L X 5$ gene and its association with carcass traits. Anim Genet 2008, 39(4):395-399.
25. Uemoto Y, Sato S, Ohnishi C, Terai S, Komatsuda A, Kobayashi E: The effects of single and epistatic quantitative trait loci for fatty acid composition in a Meishan X Duroc crossbred population. J Anim Sci 2009, 87(11):3470-3476

26. Bagnicka E, Siadkowska E, Strzalkowska N, Zelazowska B, Flisikowski K, Krzyzewski J, Zwierzchowski L: Association of polymorphisms in exons 2 and 10 of the insulin-like growth factor 2 (IGF2) gene with milk production traits in Polish Holstein-Friesian cattle. J Dairy Res 2010, 77(1):37-42.

27. Berkowicz EW, Magee DA, Sikora KM, Berry DP, Howard DJ, Mullen MP, Evans RD, Spillane C, Machugh DE: Single nucleotide polymorphisms at the imprinted bovine insulin-like growth factor 2 (IGF2) locus are associated with dairy performance in Irish Holstein-Friesian cattle. J Dairy Res 2010.

28. Spencer HG: Effects of genomic imprinting on quantitative traits. Genetica 2009, 136:285-293.

29. Patten MM, Haig D: Reciprocally imprinted genes and the response to selection on one sex. Genetics 2008, 179(3):1389-1394.

30. Spencer HG: Population genetics and evolution of genomic imprinting. Annu Rev Genetics 2002, 34:457-477.

31. de Koning DJ, Bovenhuis $\mathrm{H}$, van Arendonk JA: On the detection of imprinted quantitative trait loci in experimental crosses of outbred species. Genetics 2002, 161(2):931-938.

32. Kim J, Bergmann A, Lucas S, Stone R, Stubbs L: Lineage-specific imprinting and evolution of the zinc-finger gene ZIM2. Genomics 2004, 84(1):47-58.

33. Kim J, Bergmann A, Choo JH, Stubbs L: Genomic organization and imprinting of the Peg3 domain in bovine. Genomics 2007, 90(1):85-92

34. Tveden-Nyborg PY, Alexopoulos NI, Cooney MA, French AJ, Tecirlioglu RT, Holland MK, Thomsen PD, D'Cruz NT: Analysis of the expression of putatively imprinted genes in bovine peri-implantation embryos. Theriogenology 2008, 70(7):1119-1128.

35. Khatib H, Zaitoun I, Kim ES: Comparative analysis of sequence characteristics of imprinted genes in human, mouse, and cattle. Mamm Genome 2007, 18(6-7):538-547.

36. Henckel A, Arnaud P: Genome-wide identification of new imprinted genes. Brief Funct Genomics 2010, 9(4):304-314

37. Morison IM, Ramsay JP, Spencer HG: A census of mammalian imprinting Trends Genet 2005, 21(8):457-465.

38. Bischoff SR, Tsai S, Hardison N, Motsinger-Reif AA, Freking BA, Nonneman D, Rohrer G, Piedrahita JA: Characterization of conserved and nonconserved imprinted genes in swine. Biol Reprod 2009, 81(5):906-920.

39. Kim J, Bergmann A, Stubbs L: Exon sharing of a novel human zinc-finger gene, ZIM2, and paternally expressed gene 3 (PEG3). Genomics 2000, 64(1):114-118

40. Li L, Keverne EB, Aparicio SA, Ishino F, Barton SC, Surani MA: Regulation of maternal behavior and offspring growth by paternally expressed Peg3. Science 1999, 284(5412):330-333.

41. Lui JC, Finkielstain GP, Barnes KM, Baron J: An imprinted gene network that controls mammalian somatic growth is down-regulated during postnatal growth deceleration in multiple organs. Am J Physiol Regul Integr Comp Physiol 2008, 295(1):R189-196.

42. Finkielstain GP, Forcinito P, Lui JC, Barnes KM, Marino R, Makaroun S, Nguyen $V$, Lazarus JE, Nilsson $O$, Baron J: An extensive genetic program occurring during postnatal growth in multiple tissues. Endocrinology 2009, 150(4):1791-1800

43. Sayers EW, Barrett $\mathrm{T}$, Benson DA, Bolton E, Bryant $\mathrm{SH}$, Canese $\mathrm{K}$ Chetvernin V, Church DM, Dicuccio M, Federhen S, et al: Database resources of the National Center for Biotechnology Information. Nucleic Acids Res 2010, 38(Database issue):D5-16.

44. Lewontin RC: The interaction of selection and linkage. I. General considerations; heterotic models. Genetics 1964, 49(1):49-67.

45. Hill WG, Robertson A: Linkage disequilibrium in finite populations. Theor Applied Genet 1968, 38:226-231.

46. Barrett JC, Fry B, Maller J, Daly MJ: Haploview: analysis and visualization of LD and haplotype maps. Bioinformatics 2005, 21(2):263-265.

47. Berry DP, Shalloo L, Cromie AR, Veerkamp RF, Dillion P, Amer PR, Kearney JF, Evans RD, Wickham B: The economic breeding index: a generation on. Technical report to the Irish Cattle Breeding Federation, February 2007. 2007, 29-34.

48. Waters SM, McCabe MS, Howard DJ, Giblin L, Magee DA, MacHugh DE, Berry DP: Associations between newly discovered polymorphisms in the 
Bos taurus growth hormone receptor gene and performance traits in Holstein-Friesian dairy cattle. Anim Genet 2010.

49. Berry D, Kearney F, Harris B: Genomic selection in Ireland. Proceedings of the Interbull International Workshop: 2009; 2009 January 26-29, Uppsala, Sweden Interbull Publications, Uppsala, Sweden 2009, 29-34.

50. Gilmour AR, Cullis BR, Welham SJ, Thompson R: ASREML Reference Manual. Orange Agricultural Institute Orange: New South Wales Agriculture 2009.

51. Berry DP, Buckley F, Dillon PG, Evans RD, Veerkamp RF: Genetic relationships among linear type traits, milk yield, body weight, fertility and somatic cell count in primiparous dairy cows. Irish Journal of Agricultural and Food Research 2004, 43:161-176.

52. Carlson CS, Eberle MA, Kruglyak L, Nickerson DA: Mapping complex disease loci in whole-genome association studies. Nature 2004, 429(6990):446-452.

53. Noble WS: How does multiple testing correction work? Nat Biotechnol 2009, 27(12):1135-1137.

54. Gao X, Starmer J, Martin ER: A multiple testing correction method for genetic association studies using correlated single nucleotide polymorphisms. Genet Epidemiol 2008, 32(4):361-369.

55. Jorgensen TJ, Ruczinski I, Kessing B, Smith MW, Shugart YY, Alberg AJ: Hypothesis-driven candidate gene association studies: practical design and analytical considerations. Am J Epidemiol 2009, 170(8):986-993.

56. Gao X, Becker LC, Becker DM, Starmer JD, Province MA: Avoiding the high Bonferroni penalty in genome-wide association studies. Genet Epidemiol 2010, 34(1):100-105.

57. Ron M, Weller J: From QTL to QTN identification in livestock-winning by points rather than knock-out: a review. Anim Genet 2007, 38(5):429-439.

58. Lin WY, Lee WC: Incorporating prior knowledge to facilitate discoveries in a genome-wide association study on age-related macular degeneration. BMC Res Notes 2010, 3(26).

59. Rempel LA, Nonneman DJ, Wise TH, Erkens T, Peelman LJ, Rohrer GA: Association analyses of candidate single nucleotide polymorphisms on reproductive traits in swine. J Anim Sci 2010, 88(1):1-15.

60. Tabor HK, Risch NJ, Myers RM: Candidate-gene approaches for studying complex genetic traits: practical considerations. Nat Rev Genet 2002, 3(5):391-397.

61. Wayne ML, Mclntyre LM: Combining mapping and arraying: An approach to candidate gene identification. Proc Natl Acad Sci USA 2002, 99(23):14903-14906.

62. Magee DA, Berry DP, Berkowicz EW, Sikora KM, Howard DJ, Mullen MP, Evans RD, Spillane C, Machugh DE: Single nucleotide polymorphisms within the bovine DLK1-DIO3 imprinted domain are associated with economically important production traits in cattle. J Hered 2010.

63. Bonferroni CE: Teoria statistica delle classi e calcolo delle probabilitá. Pubblicazioni del Istituto Superiore di Scienze Economiche e Commerciali di Firenze 1936, 8:3-62.

64. Safran M, Dalah I, Alexander J, Rosen N, Iny Stein T, Shmoish M, Nativ N, Bahir I, Doniger T, Krug H, et al: GeneCards Version 3: the human gene integrator. Database (Oxford) 2010, baq020.

65. Hoshiya H, Meguro M, Kashiwagi A, Okita C, Oshimura M: Calcr, a brainspecific imprinted mouse calcitonin receptor gene in the imprinted cluster of the proximal region of chromosome 6. J Hum Genet 2003, 48(4):208-211

66. Alexander LS, Qu A, Cutler SA, Mahajan A, Rothschild MF, Cai W, Dekkers JC Stahl $\mathrm{CH}$ : A calcitonin receptor $(C A L C R)$ single nucleotide polymorphism is associated with growth performance and bone integrity in response to dietary phosphorus deficiency. J Anim Sci 2010, 88(3):1009-1016.

67. Fan B, Onteru SK, Mote BE, Serenius T, Stalder KJ, Rothschild MF: Largescale association study for structural soundness and leg locomotion traits in the pig. Genet Sel Evol 2009, 41:14.

68. Liu F, Roth RA: Grb-IR: a SH2-domain-containing protein that binds to the insulin receptor and inhibits its function. Proc Natl Acad Sci USA 1995, 92(22):10287-10291.

69. Charalambous M, Cowley M, Geoghegan F, Smith FM, Radford EJ, Marlow BP, Graham CF, Hurst LD, Ward A: Maternally-inherited Grb10 reduces placental size and efficiency. Developmental Biology 2010, 337:1-8.

70. Shiura H, Nakamura K, Hikichi T, Hino T, Oda K, Suzuki-Migishima R, Kohda T, Kaneko-ishino T, Ishino F: Paternal deletion of Meg1/Grb10 DMR causes maternalization of the Meg1/Grb10 cluster in mouse proximal chromosome 11 leading to severe pre- and postnatal growth retardation. Hum Mol Genet 2009, 18(8):1424-1438.

71. Edwards CA, Ferguson-Smith AC: Mechanisms regulating imprinted genes in clusters. Curr Opin Cell Biol 2007, 19(3):281-289.

72. el-Baradi T, Pieler T: Zinc finger proteins: what we know and what we would like to know. Mechanisms of Development 1991, 35:155-169.

73. Kim J, Ashworth L, Branscomb E, Stubbs L: The human homolog of a mouse-imprinted gene, Peg3, maps to a zinc finger gene-rich region of human chromosome 19q13.4. Genome Res 1997, 7:532-540.

74. Murphy SK, Wylie AA, Jirtle RL: Imprinting of PEG3, the human homologue of a mouse gene involved in nurturing behavior. Genomics 2001, 71(1):110-117

75. Van den Veyver IB, Norman B, Tran CQ, Bourjac J, Slim R: The human homologue (PEG3) of the mouse paternally expressed gene 3 (Peg3) is maternally imprinted but not mutated in women with familial recurrent hydatidiform molar pregnancies. J Soc Gynecol Investig 2001, 8(5):305-313.

76. Pliushch G, Schneider E, Weise D, El Hajj N, Tresch A, Seidmann L, Coerdt W, Muller AM, Zechner U, Haaf T: Extreme methylation values of imprinted genes in human abortions and stillbirths. Am J Pathol 2010, 176(3):1084-1090.

77. Zechner U, Pliushch G, Schneider E, El Hajj N, Tresch A, Shufaro Y, Seidmann L, Coerdt W, Muller AM, Haaf T: Quantitative methylation analysis of developmentally important genes in human pregnancy losses after ART and spontaneous conception. Mol Hum Reprod 2010, 16(9):704-713

78. Liu JH, Yin S, Xiong B, Hou Y, Chen DY, Sun QY: Aberrant DNA methylation imprints in aborted bovine clones. Mol Reprod Dev 2008, 75(4):598-607.

79. Drake NM, Park YJ, Shirali AS, Cleland TA, Soloway PD: Imprint switch mutations at Rasgrf1 support conflict hypothesis of imprinting and define a growth control mechanism upstream of IGF1. Mamm Genome 2009, 20(9-10):654-663

80. Nash DL, Rogers GW, Cooper JB, Hargrove GL, Keown JF: Relationships among severity and duration of clinical mastitis and sire transmitting abilities for somatic cell score, udder type traits, productive life, and protein yield. J Dairy Sci 2002, 85(5):1273-1284.

81. Shook GE, Schutz MM: Selection on somatic cell score to improve resistance to mastitis in the United States. J Dairy Sci 1994, 77(2):648-658.

82. Burvenich C, Paape MJ, Hoeben D, Dosogne H, Massart-Leën AM, Blum J: Modulation of the inflammatory reaction and neutrophil defense of the bovine lactating mammary gland by growth hormone. Domest Anim Endocrinol 1999, 17(2-3):149-159.

83. Alders M, Ryan A, Hodges M, Bliek J, Feinberg AP, Privitera O, Westerveld A, Little PF, Mannens M: Disruption of a novel imprinted zinc-finger gene, ZNF215, in Beckwith-Wiedemann syndrome. Am J Hum Genet 2000, 66(5):1473-1484

84. Williams AJ, Khachigian LM, Shows T, Collins T: Isolation and characterization of a novel zinc-finger protein with transcription repressor activity. J Biol Chem 1995, 270(38):22143-22152.

85. Witzgall R, O'Leary E, Leaf A, Onaldi D, Bonventre JV: The Kruppelassociated box-A (KRAB-A) domain of zinc finger proteins mediates transcriptional repression. Proc Natl Acad Sci USA 1994, 91(10):4514-4518.

86. Weksberg R, Shuman C, Beckwith JB: Beckwith-Wiedemann syndrome. Eur J Hum Genet 2010, 18(1):8-14.

87. Stinckens A, Van den Maagdenberg K, Luyten T, Georges M, De Smet S, Buys N: The RYR1 g.1843C > T mutation is associated with the effect of the IGF2 intron3-g.3072G > A mutation on muscle hypertrophy. Anim Genet 2007, 38(1):67-71.

88. Neilson JR, Sandberg R: Heterogeneity in mammalian RNA 3' end formation. Exp Cell Res 2010, 316(8):1357-1364.

89. Zhao J, Hyman L, Moore C: Formation of mRNA 3' ends in eukaryotes: mechanism, regulation, and interrelationships with other steps in mRNA synthesis. Microbiol Mol Biol Rev 1999, 63(2):405-445.

90. Conne B, Stutz A, Vassalli JD: The $3^{\prime}$ untranslated region of messenger RNA: A molecular 'hotspot' for pathology? Nat Med 2000, 6(6):637-641.

91. Sasaki S, Yamada T, Sukegawa S, Miyake T, Fujita T, Morita M, Ohta T, Takahagi $Y$, Murakami $H$, Morimatsu F, et al: Association of a single nucleotide polymorphism in akirin 2 gene with marbling in Japanese Black beef cattle. BMC Res Notes 2009, 2:131.

92. Kgwatalala PM, Ibeagha-Awemu EM, Hayes JF, Zhao X: Stearoyl-CoA desaturase 1 3'UTR SNPs and their influence on milk fatty acid 
composition of Canadian Holstein cows. J Anim Breed Genet 2009, 126(5):394-403.

93. Duthie CA, Simm G, Perez-Enciso M, Doeschl-Wilson A, Kalm E, Knap PW, Roehe R: Genomic scan for quantitative trait loci of chemical and physical body composition and deposition on pig chromosome $\mathrm{X}$ including the pseudoautosomal region of males. Genet Sel Evol 2009, 41:27.

94. Markljung E, Braunschweig MH, Karlskov-Mortensen P, Bruun CS, Sawera M, Cho IC, Hedebro-Velander I, Josell A, Lundstrom $K$, von Seth $G$, et al: Genome-wide identification of quantitative trait loci in a cross between Hampshire and Landrace II: meat quality traits. BMC Genet 2008, 9:22.

95. Karlskov-Mortensen P, Bruun CS, Braunschweig MH, Sawera M, Markljung E, Enfalt AC, Hedebro-Velander I, Josell A, Lindahl G, Lundstrom K, et al: Genome-wide identification of quantitative trait loci in a cross between Hampshire and Landrace I: carcass traits. Anim Genet 2006, 37(2):156-162.

96. Rattink AP, De Koning DJ, Faivre M, Harlizius B, van Arendonk JA, Groenen MA: Fine mapping and imprinting analysis for fatness trait QTLs in pigs. Mamm Genome 2000, 11(8):656-661.

97. Hickey JM, Keane MG, Kenny DA, Cromie AR, Veerkamp RF: Genetic parameters for EUROP carcass traits within different groups of cattle in Ireland. J Anim Sci 2007, 85(2):314-321.

doi:10.1186/1471-2156-11-93

Cite this article as: Magee et al.: DNA sequence polymorphisms in a panel of eight candidate bovine imprinted genes and their association with performance traits in Irish Holstein-Friesian cattle. BMC Genetics 2010 11:93.

\section{Submit your next manuscript to BioMed Central and take full advantage of:}

- Convenient online submission

- Thorough peer review

- No space constraints or color figure charges

- Immediate publication on acceptance

- Inclusion in PubMed, CAS, Scopus and Google Scholar

- Research which is freely available for redistribution

Submit your manuscript at www.biomedcentral.com/submit 